Article

\title{
Economic Analysis and Improvement Opportunities of African Catfish (Clarias gariepinus) Aquaculture in Northern Germany
}

\author{
Johannes Pasch * and Harry W. Palm \\ Department of Aquaculture and Sea-Ranching, Faculty of Agricultural and Environmental Science, \\ University of Rostock, D-18059 Rostock, Germany; harry.palm@uni-rostock.de \\ * Correspondence: johannes.pasch@uni-rostock.de; Tel.: +49-178-6570697
}

Citation: Pasch, J.; Palm, H.W. Economic Analysis and Improvement Opportunities of African Catfish (Clarias gariepinus) Aquaculture in Northern Germany. Sustainability 2021, 13, 13569. https://doi.org/ $10.3390 /$ su132413569

Academic Editor:

Giuseppe Antonio Di Vita

Received: 8 November 2021

Accepted: 3 December 2021

Published: 8 December 2021

Publisher's Note: MDPI stays neutral with regard to jurisdictional claims in published maps and institutional affiliations.

Copyright: (c) 2021 by the authors. Licensee MDPI, Basel, Switzerland. This article is an open access article distributed under the terms and conditions of the Creative Commons Attribution (CC BY) license (https:/ / creativecommons.org/licenses/by/ $4.0 /)$.

\begin{abstract}
A farmland based African Catfish recirculation aquaculture system with a production volume (PV) of $300 \mathrm{~m}^{3}$ was modelled under realistic market conditions in order to analyse the impact of price fluctuations on profitability. As a monoculture recirculating aquaculture system (RAS) for whole fish and the wholesaler's market, the model northern German catfish aquaculture is currently gainless, but the production is sufficient to cover all costs. The most decisive economic parameter is the low selling price (2.20 EUR/ kg whole fish), which affects the returns by $\pm 70,463 \mathrm{EUR} /$ year for every ten percent ( 0.22 EUR) price change. Among the variable costs, feed has by far the largest impact with a share of $61.4 \%(42.1 \%$ of total costs). Based on the initial model every ten percent price variation of this variable input factor changes the returns by $\pm 29,691$ EUR/year, followed by energy ( \pm 5913 EUR/year), fingerlings ( \pm 4804 EUR/year), wages ( \pm 3972 EUR/year) and water ( \pm 2464 EUR/year). Larger system sizes (600 m3 PV) significantly save costs due to economies of scale and achieve returns of $175,240 \mathrm{EUR} /$ year and an ROI of $11.45 \%$. Increasing max. stocking density from $450 \mathrm{~kg} / \mathrm{m}^{3}$ to $550 \mathrm{~kg} / \mathrm{m}^{3}$ improves returns and ROI (40,379 EUR/year; $4.40 \%$ ), but also involves higher production risks. An own fingerling production with a production of $300 \%$ above the own requirements improves returns and ROI (39,871 EUR/year; 3.57\%) and leads, above all, to independence from foreign suppliers. Aquaponic integrations can generate profits, but are associated with high investment costs and the challenges of entering a new business sector. Product diversification into fillet ( $50 \%$ of the production) and smoked fillet $(30 \%)$ generates lucrative returns and ROI (212,198 EUR/year; $20.10 \%)$. Profitability is further increased by direct marketing in the form of a farm store and the establishment of a regional "producer organisation". Our results demonstrate that under current market conditions northern German catfish aquaculture covers all costs, mainly increasing profitability through altered sales prices and feed costs. Retaining a larger part of the fishery value chain within the farm through additional benefits, further processing and product diversification improves profitability, making African catfish RAS a sustainable and economically profitable aquaculture business in Germany.
\end{abstract}

Keywords: aquaculture; aquaponics; economies of scale; RAS; profitability; ROI; value chain

\section{Introduction}

Global aquaculture production has increased significantly by 193\% from 1999 (41 mil. tons/year) to 2019 (120 mil. tons/year), with the majority of the production (91.6\%) coming from Asian aquaculture [1]. Europe had a small share of global aquaculture (2.7\%) in 2017 with an annual growth rate of $2.27 \%$ per year since 2000 [2]. The past years European Aquaculture growth is stagnating in many countries [3], also in Germany [4]. This is despite the fact that the European Commission is seeking for new solutions increasing sustainable aquaculture production inside the member states [5]. Recirculation aquaculture systems (RAS) have been recognised as an alternative to open water and netcage aquaculture, enabling higher stocking densities, reducing water consumption and controlling nutrient and wastewater release [6,7]. With a yearly production volume of 23,000 tons 
in 2018, European RAS always had stable shares between $1.5-2 \%$ of the total production volume since 2009 [8]. In combination with plant production, so called aquaponics can be considered a contemporary and ecologically sustainable agricultural production system that supports the development of a recycling economy [9]. It can be integrated into the existing value chains, either coming from the aquaculture or the plant production side.

While the intensive production of salmonids in RAS has been established in Scandinavia, Denmark [10,11] and Poland [12], more challenging species such as pikeperch (Sander lucioperca) are still under development [13]. Successful RAS of African catfish (Clarias gariepinus) in Europe has been developed in the Netherlands and also introduced to Germany and other European countries [14]. Combined with alternative energies and cheap warm water sources, e.g., from biogas plants [15], commercial production of C. gariepinus in warm water RAS has increased in Germany notably by 221\% between 2011 (319 t/year) [9] and 2020 (1025 t/year) [16]. African catfish RAS has the advantage that Clarias gariepienus can be cultivated under high stocking densities [17-19], reaches survival rates above $90 \%$ [20] and can withstand adverse water conditions [21,22]. Therefore, the combination of African catfish and RAS is applicable under regular farming conditions, reducing costs of energy and water as well as reutilising the nutrient enriched solids and wastewater on the farm.

African catfish products reach quality attributes of fillets superior to other catfish species such as European catfish (Silurus glanis), African catfish hybrid (Heterobranchus longifilis $x$ Clarias gariepinus) distributed under the brand name Claresse ${ }^{\circledR}$ and Pangasius (Pangasianodon hypophthalmus) [23]. This is nowadays recognised also on German markets, seeking new investments into African catfish RAS and further increasing production capacity. In addition, several studies demonstrated that African catfish effluents can be used in aquaponics to produce valuable plant products such as basil (Ocimum basilicum) [24-26], mint (Mentha spicata) [27] and pumpkin (Telfairia occidentalis) [28]. However, the development of African catfish farms in Germany were primarily promoted by the European Maritime and Fishery Fund (EMFF) [29] in the form of investment subsidies of up to $49 \%$, but were also supported by the Renewable Energy Law (EEG), where the use of warm water from biogas production inside the RAS was compensated with an additional subsidy (Combined Heat and Power bonus-CHP) [30,31]. The different market conditions, locations and policies, but also reports about RAS unprofitability $[4,32]$ and whitewashed figures of plant manufacturers make it difficult for the future investor to calculate profitability of new African catfish RAS. In addition, the systems currently in use in northern Germany have not been further developed under consideration of new water filtration systems, cultivation conditions, and management strategies.

There is a variety of recent publications on RAS systems with a scientific focus on water or solid treatment [33-35], nutrient flows [36-38], bacterial activities [39-41], or aquaponic adaption [42-44]. Although economic performance is the most critical issue for the long-term successful operation of RAS, research on this issue, especially for particular species is scarce. A detailed economic review of a Tilapia prototype RAS dates from 1996 and describes three tools or models for analysing a Tilapia RAS or an investment in such a system [45]. A 2012 study on management issues in RAS identified the main problem as inadequately trained employees taking responsibility for water treatment and mechanical problems [6]. In addition, a lack of research on commercial scale RAS was identified, which is a key priority to improve performance. Similar findings were again published in a 2020 study, which identified poor management, lack of technology knowledge, high investments, and incidence of disease and pathogens as the main problems for the RAS industry. [46] A study on the economic feasibility of pangasius RAS in Vietnam concluded that $99 \%$ of investments in medium or large RAS are profitable and crucial parameters are price, yield, fingerlings, feed and investment. [47]. A recent EUMOFA (European Market Observatory for Fisheries and Aquaculture Products) publication on RAS has identified financial risk as one of the main risks, primarily due to high capital expenditure and uncertainty regarding future costs [8]. Further actual studies on RAS profitability 
primarily address topics such as nursery of marine fish seeds [48,49], hatchery of carp or overwintering of carp juveniles [50,51], or the production of ornamental fish [52,53]. Whereas there are many recent economic studies for the African catfish particularly from Africa and Asia [54-56], and the importance of input factors like the feed price onto profitability of regular aquaculture systems has been very well described [57-59] the driving cost factors for African catfish RAS including the key production factors have not been analysed.

We herewith calculate the actual cost structure of African catfish RAS in northern Germany based on a model farm and regular market conditions. The different variable costs are arranged in a descending order, and allow analyses of the real effects of price fluctuations and different entrepreneurial decision scenarios on key performance indicators (KPI), illustrating the potential of cost control and system improvements. Two aquaponic scenarios allow an estimation of additional costs and benefits. Profitability and the best options to improve the economic and ecologic sustainability of these highly productive aquaculture systems are discussed.

\section{Materials and Methods}

All data and information for this study originate from regional African catfish farms, feed producers, energy providers, seedling producers and water suppliers, greenhouse producers as well as own data from running African catfish RAS systems and experiments in the FishGlassHouse, University of Rostock. Depending on the location, supplier contract, and scaling, the values may differ to a certain degree. The possible price and value ranges are given and an average calculation basis (CB) was chosen for the initial model.

\subsection{African Catfish RAS-Initial Model}

An average catfish recirculating aquaculture system (RAS) in Mecklenburg-Western Pomerania with a production volume (PV) of $300 \mathrm{~m}^{3}$ (recirculation volume $390 \mathrm{~m}^{3}$ ) was modelled (Figure 1). The facility was divided into four closed loops (Unit 1-4), each with 14 rearing tanks of $5 \mathrm{~m}^{3}$ and two fingerling fish tanks of $2.5 \mathrm{~m}^{3}$ each. A simplified smaller sized system has been described for the FishGlassHouse [9]. Each unit consists of four settling tanks (sedimenter) and four pump sumps, each with a biofilter installed above. The fish are fed with an automatic feeder. On average, $2.5 \%$ of the tanks are empty due to fish slaughter, restocking or cleaning, resulting in a net production volume of $292.5 \mathrm{~m}^{3}$. The investment costs are significantly influenced by scaling and location and range from 4500-7500 EUR $/ \mathrm{m}^{3}$ PV. As a calculation basis (CB) $6000 \mathrm{EUR} / \mathrm{m}^{3} \mathrm{PV}$ was chosen, which resulted in total investment costs (TIC) of 1,800,000 EUR.

The stocking density at slaughter or the average stocking density is a crucial variable and influences the total production output of any aquaculture farm and thus almost all other variables. For instance, the main input factors feed, seedlings, labour and water increase while energy consumption remains similar with increasing stocking densities. Average stocking densities of commercial African catfish RAS in northern Germany range between $350-550 \mathrm{~kg} / \mathrm{m}^{3} \mathrm{PV}$ stocking density at slaughter. The max stocking density at slaughter of $450 \mathrm{~kg} / \mathrm{m}^{3}$ PV was chosen as CB, which corresponds to an average stocking density of $180 \mathrm{~kg} / \mathrm{m}^{3} \mathrm{PV}$ or $300 \mathrm{fish} / \mathrm{m}^{3} \mathrm{PV}$. This yields an annual production of $320,288 \mathrm{~kg} /$ year. 


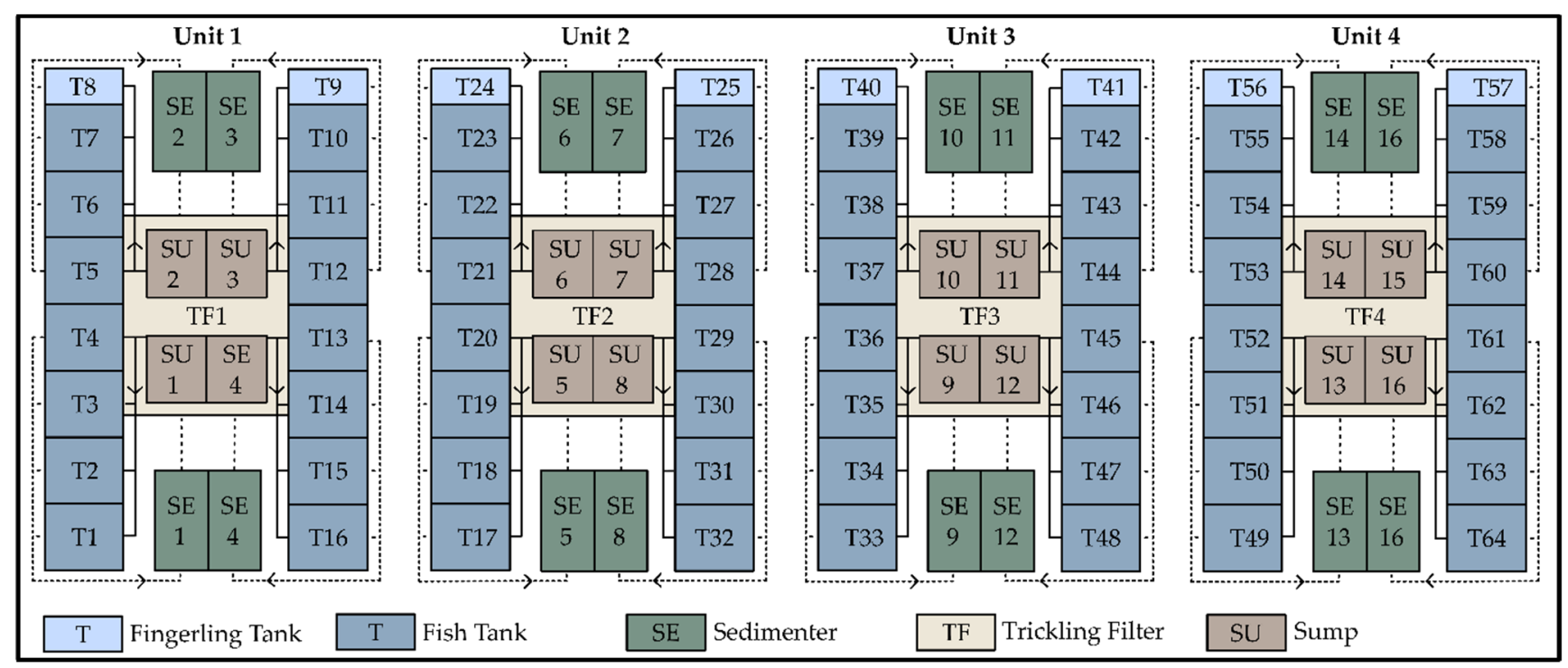

Figure 1. Illustration of the $300 \mathrm{~m}^{3}$ African catfish RAS initial model. The system is divided into four independent loops.

\subsubsection{Variable Costs}

Feed is the main cost driver in intensive aquaculture. Depending on the FCR (Feed Conversion Ratio) and feed type, feed costs vary. Economies of scale also result in better contract conditions and higher kickbacks. For this research, the use of three feeds differing in size and expense from Coppens (Alltech Coppens BV, Leende, Netherlands) was assumed. It is common to feed the fingerlings 2 weeks with $2 \mathrm{~mm}$ feed, then 3 weeks with $3 \mathrm{~mm}$ and in the fattening phase approx. 17 weeks with $4.5 \mathrm{~mm}$ feed [60]. The different feed costs and quantities added together result in ranges of $0.90-1.16 \mathrm{EUR} / \mathrm{kg}$ feed. For this work, an average price of 1.03 EUR/ $\mathrm{kg}$ (CB) was chosen. The FCR depends on many factors such as stocking density, feed (frequency), fish homogeneity and other husbandry conditions such as physico-chemical water parameters. Feed manufacturers report an average FCR of 0.85 for the entire growth period [61]. Dutch catfish farming is reported at 0.80 , while studies on intensive production come to a different range with FCRs of $0.83-0.90$ for adult catfish $>1 \mathrm{~kg}$ [19] or 0.94-1.07 for staggered production semi-commercial experiments [9]. The CB for this study was set at an FCR of 0.90 , which corresponds to a total feed consumption of $288,259 \mathrm{~kg} /$ year and costs of 296,907 EUR/year.

Energy costs depend on whether the energy is produced in-house or by an affiliate company, or whether it is purchased publicly. In African Catfish aquaculture of Mecklenburg-Western Pomerania, companies are usually integrated into a group of affiliated companies and complement each other in production. It is common for large catfish farms to have an affiliate's biogas-CHP plant generate electricity and heat that is used by the fish farm. It depends on the type of desired taxation and accounting by each company, but relatively low purchase prices are standard. A gas price range of $0.02-0.04 \mathrm{EUR} / \mathrm{kWh}(\mathrm{CB}$ $0.03 \mathrm{EUR} / \mathrm{kWh}$ ) with a consumption range of $8-12 \mathrm{kWh} / \mathrm{m}^{3} \mathrm{PV} / \mathrm{d}\left(\mathrm{CB} 10 \mathrm{kWh} / \mathrm{m}^{3} \mathrm{PV} / \mathrm{d}\right)$ would lead to a gas demand of $1095 \mathrm{MWh} /$ year and costs of 32,850 EUR/year. Since the biomass for energy production is usually produced in affiliate companies, a possible $\mathrm{CHP}$ bonus will not be counted towards aquaculture in this work. An electric energy purchase price ranges between $0.06-0.10 \mathrm{EUR} / \mathrm{kWh}(\mathrm{CB} 0.08 \mathrm{EUR} / \mathrm{kWh})$ with an electricity consumption range of $2-4 \mathrm{kWh} / \mathrm{m}^{3} \mathrm{PV} / \mathrm{d}\left(\mathrm{CB}\right.$ of $\left.3 \mathrm{kWh} / \mathrm{m}^{3} \mathrm{PV} / \mathrm{d}\right)$, and results in an annual consumption of $328.5 \mathrm{MWh} /$ year and costs of $26,280 \mathrm{EUR} /$ year. Heat and electricity thus result in total energy costs of 59,130 EUR/year.

The fingerlings $(12 \mathrm{~g})$ are purchased from local or Dutch fingerling producers. The price range is $0.07-0.33$ EUR per fish. As CB, $0.20 \mathrm{EUR} /$ fish was chosen. C. gariepinus grows from $12 \mathrm{~g}$ to a slaughter weight of $1.5 \mathrm{~kg}$ in 5 months. For each $\mathrm{kg}$ of catfish growth, an average of 0.72-0.78 fingerlings is needed, which includes mortality. As CB, 
0.75 fingerlings $/ \mathrm{kg}$ were chosen, which, with an annual production of 320,288 $\mathrm{kg} /$ year, leads to a total requirement of 240,216 fingerlings at a price of 48,043 EUR/year.

The working hours and thus the wages depend on the desired processing stages and the working speed. For the initial model, the production of $100 \%$ whole fish or living fish is assumed, which means employees would mostly sort fishes and clean. As the jobs do not require special qualifications, a full-time unskilled employee can be hired slightly above minimum wage with a range of 29,000-33,000 EUR/year (incl. non-wage labour costs). For this farm, a CB of 31,000 EUR/year was chosen. One worker can handle approx. 150-350 t/year depending on the degree of automation of the RAS. With a CB of $250 \mathrm{t} /$ year, 1.28 employees/year are required at labour costs of 39,716 EUR/year.

The costs for fresh, industrial and wastewater depend on whether the water is drawn from one's own well or comes from suppliers and whether the wastewater is treated on own land or can be further used. The total water costs therefore range from $0.35-2.70 \mathrm{EUR} / \mathrm{m}^{3}$, including wastewater. Since all large catfish farms obtain their water from own wells and partly also have their own treatment and utilisation possibilities, the CB of $0.90 \mathrm{EUR} / \mathrm{m}^{3}$ was chosen. The stocking density is the decisive variable for water consumption. The higher the stocking density, the higher the water exchange rate must be to ensure sufficient water quality. At a slaughter density of $450 \mathrm{~kg} / \mathrm{m}^{3}$ (average stocking density $180 \mathrm{~kg} / \mathrm{m}^{3}$ ), the exchange rate must be $22.5-27.5 \% /$ day, including the consumption of veterinary facilities and slaughtering. With a CB of $25 \%, 27,375 \mathrm{~m}^{3} /$ year are consumed at costs of 24,638 EUR/year.

Further variable costs such as veterinary drugs, external services or material and production costs were summarised as an amount of 15,000 EUR. The transport costs are included in the sales prices. The total variable costs in the initial model are 483,433 EUR/year.

\subsubsection{Fixed Costs}

Depreciation is listed as the main costs among the fixed costs. The total investment (1.80 mil. EUR) is divided into material and equipment (1,309,091 EUR) and construction (490,909 EUR). Material and equipment have, depending on the equipment, a straightline depreciation period of 8-12 years. The CB was therefore simplified to 10 years, which corresponds to a depreciation of 130,909 EUR/year. Construction is more persistent and is depreciated on a straight-line basis over 20 years, which corresponds to $24,545 \mathrm{EUR} /$ year and leads to a total depreciation of 155,455 EUR/year. The system needs a manager/administrator, who incurs costs of 45,000 EUR/year. Other fixed costs, such as demand rate net (electric energy), insurance, maintenance, etc., were summarised as costs of 20,745 EUR/year. Investments are financed with different proportions of equity, debt and subsidies. For the purpose of this paper, the KPI analysis of one year of operation, a simplified form of mixed financing with $51 \%$ equity and $49 \%$ subsidies was assumed, which eliminates interest. Since the North German investors are farmers, land ownership was assumed, which also eliminates rent. A possible rededication of available production halls, significantly reducing investment costs, was not considered. Total fixed costs of 221,220 EUR/year occur.

\subsubsection{Revenues}

The revenues are determined by the processing stage and the sales price. For the initial model it is assumed that $100 \%$ of the fish is sold as whole fish or living fish. Assuming a mixed distribution of $80-90 \%$ to holesale and $10-20 \%$ to Retail, the producer prices for whole/living C. gariepinus in 2021 in northern Germany range between 1.70-2.70 EUR/kg. An average selling price (CB) of $2.20 \mathrm{EUR} / \mathrm{kg}$ can be achieved. The total production of $320,288 \mathrm{~kg} /$ year generates revenues of 704,633 EUR/year.

\subsection{Entrepreneurial Decision Scenarios}

In the following analyses, the impact of decision scenarios on the profitability of the initial model was investigated. 


\subsubsection{Scenario 1-Double Production Volume}

Doubling the production volume from $300 \mathrm{~m}^{3}$ to $600 \mathrm{~m}^{3}$ would result in a doubling of all input quantities (feed, fingerlings, energy, water), but at the same time quantities can be economised or prices reduced through improved economies of scale [12]. This primarily concerns the investment costs, which drop to $5000 \mathrm{EUR} / \mathrm{m}^{3} \mathrm{PV}$ ( 3 mil. EUR). The costs for feed and fingerlings are reduced by $5 \%$ each due to double purchase quantities, energy costs by $10 \%$. The doubled production volume requires only $85 \%$ more labour. Other fixed costs increase by $75 \%$.

\subsubsection{Scenario 2-Higher Stocking Density}

The increase in max. stocking density from $450 \mathrm{~kg} / \mathrm{m}^{3}$ to $550 \mathrm{~kg} / \mathrm{m}^{3}$ (Average stocking density $220 \mathrm{~kg} / \mathrm{m}^{3}, 367 \mathrm{fish} / \mathrm{m}^{3}$ ) results in the FCR decreasing to 0.93 and 0.77 fingerlings $/ \mathrm{kg}$ growth being required. In addition, due to increased filter cleaning and water monitoring, one employee only manages $200 \mathrm{t} /$ year and the water exchange rate increases to $30 \%$ / day.

\subsubsection{Scenario 3-Fingerling Production}

Fingerlings are produced in-house and require a separate room. As a result of its complexity, broodstock facility and maintenance was not separated in this calculation because the broodstock can also be co-cultivated in the main fish farm.

Option 1: Fingerlings are produced for the company's own use only. In-house fingerling production raises total investment costs to $7000 \mathrm{EUR} / \mathrm{m}^{3} \mathrm{PV}$ (2.1 mil. EUR) for the production volume of 300 to and fingerlings due to the need for an additional protected rearing room with tanks and equipment. Larval and fingerling feed requirements increase feed costs by $3 \%$, and energy and water costs increase by $10 \%$. Fingerling production requires the hiring of a higher-skilled employee which increases labour costs by $75 \%$. Other fixed costs increase by $10 \%$. Saved variable costs are used to calculate KPIs for fingerlings.

Option 2: The farm produces $300 \%$ of its own needs (720,647 fingerlings/year) and resells $200 \%$ for $0.20 \mathrm{EUR} /$ fingerling. The rearing room and special equipment from option 1 are already existing and the rearing tanks, pipes and pumps lead to a small increase in investment costs to $7300 \mathrm{EUR} / \mathrm{m}^{3} \mathrm{PV}$ (2.19 mil. EUR). The initial feed costs increase by only $7.5 \%$ due to better contract conditions, while energy and water costs increase by $15 \%$. The trained employee learns cheaper labour for the repetitive tasks and the original labour costs increase only by $90 \%$. The other fixed costs increase by $25 \%$.

\subsubsection{Scenario 4-Aquaponic Integration}

For the calculation of an aquaponic integration, two greenhouse models were calculated using KTBL (Kuratorium für Technik und Bauwesen) online applications, which include costs of debt [62,63]. The price level from 2013 was increased by a factor of 1.33 using the price index of the Federal Statistical Office for commercial buildings and thus adjusted to the level of the second quarter of 2021.

Option 1 is a small $1000 \mathrm{~m}^{2}$ greenhouse for the production of one series of tomatoes on the vine per year that are distributed to food retail market (decoupled aquaponics s.s. according to Palm et al. 2018 [64]). Tomatoes were chosen because they achieve high market prices and can produce competitive yields with improved fertiliser use efficiency in decoupled aquaponics [65]. A Venlo greenhouse was chosen, with special glass, gutter culture, drip irrigation and blackout/shading/heat insulation screen on roof and side walls which costs 509,548 EUR (509.55 EUR/ $\mathrm{m}^{2}$ ) without artificial lighting. The variable costs include seeds and seedlings, culture pots and substrates, plant protection, fertilisation and irrigation, packaging, wages and other costs and amount to $0.99 \mathrm{EUR} / \mathrm{kg}$ tomato. Due to the $28{ }^{\circ} \mathrm{C}$ warm water of the fish farm, heating, water and fertiliser costs of the greenhouse reduce the variable costs by $3.03 \%$ to $0.96 \mathrm{EUR} / \mathrm{kg}$. For tomatoes on the vine, a yield of $53 \mathrm{~kg} / \mathrm{m}^{2}$ are to be expected, resulting in $53 \mathrm{t} /$ year and variable costs of 50,880 EUR/year. Fixed costs (depreciation, interests, repairs, insurance and other costs) 
amount to 65,690 EUR/year. Tomatoes produced in aquaponics can be marketed alike organic tomatoes and achieve a selling price of $2.50 \mathrm{EUR} / \mathrm{kg}$.

Option 2 is a $10,000 \mathrm{~m}^{2}$ Venlo greenhouse for basil production with special glass and screens on the roof and side walls but with ebb and flow cultivation systems and LED assimilation lighting (decoupled aquaponics s.l. according to Palm et al. 2018 [64]). Despite economies of scale, the greenhouse costs a total of 4,474,565 EUR $\left(447.46 \mathrm{EUR} / \mathrm{m}^{2}\right)$ due to high-quality lighting. The variable costs are highly dependent on the season. The variable production costs of a pot are $0.57 \mathrm{EUR} /$ pot in winter due to the increased heating and electricity costs and only $0.36 \mathrm{EUR} /$ pot in summer. The average variable costs are $0.429 \mathrm{EUR} /$ pot and are reduced by $4.66 \%$ to $0.409 \mathrm{EUR} /$ pot due to the yearly warm water supply with the aquaculture process water. Assimilation lighting enables ten five-week growth cycles, which, with 25 basil pots $/ \mathrm{m}^{2}$, results in an annual production of 2.5 million pots and thus variable costs of 1,021,875 EUR/year. The fixed costs amount to 748,832 EUR/year. Marketing the product as aquaponic sustainable food, the average sales price of the plants achieves $0.85 \mathrm{EUR} /$ pot for mixed sales by wholesale and retail. If at least $95 \%$ of the 2.5 million pots are marketable products, 2,375,000 basil pots/year will be sold.

For aquaponic integration, transition tanks and piping from the fish farm to plant farm must be installed, which increases the investment costs of the fish farm to $6300 \mathrm{EUR} / \mathrm{m}^{3}$ PV (1.89 mil. EUR). In addition, management and administrative costs can be saved by overlapping administrative tasks. For this model, savings were attributed to aquaculture, and $20 \%$ lower management costs are calculated. The main benefits of aquaponic integration are the improved marketing opportunities of fish and plants, which in aquaculture leads to an increase in the fish selling price of $5 \%(2.31 \mathrm{EUR} / \mathrm{kg})$.

\subsubsection{Scenario 5-Higher Value-Added Level}

Scenario 5 analyses the impact of a higher value-added level through higher processing stages and direct marketing. Labour costs for simple, repetitive tasks such as filleting, smoking and selling remain at a CB of 31,000 EUR/year. For the whole process of filet production, from emptying a tank to slaughtering, filleting, packing and freezing, there is a wide range given from 15-35 kg fillet/hour/worker (CB $25 \mathrm{~kg} /$ hour). From higher finishing levels such as smoked fillet, $7.5-12.5 \mathrm{~kg} /$ hour/worker (CB $10 \mathrm{~kg} / \mathrm{hour}$ ) can be produced. The average fillet price ranges between $5-8 \mathrm{EUR} / \mathrm{kg}$ (CB 6,50 EUR $/ \mathrm{kg}$ ), the average smoked fillet price varies between 10-15 EUR $/ \mathrm{kg}$ (CB 12,50 EUR $/ \mathrm{kg})$. The African catfish has a fillet yield of $41 \%$. The trimmings (59\%) produced at slaughter can be sold for 40-60 EUR/t (CB $50 \mathrm{EUR} / \mathrm{t}$ ). Transport, packaging and smoking requirements are included in the selling prices. Three different marketing and price variants were modelled and analysed.

In option 1, 20\% of the total output is sold as whole fish and $80 \%$ is filleted. Due to the integration of a slaughter room including a cooling plant, the investment costs increase by $10 \%$ to $6600 \mathrm{EUR} / \mathrm{m}^{3}$ PV (1.98 mil. EUR). The cooling system and the additional consumption of drinking water lead to an increase in electricity and water costs of $10 \%$. Labour costs increase by 77,540 EUR/year due to an additional 2.5 workers/year. The yearly production amounts $64,058 \mathrm{~kg}$ of whole fish, 105,054 $\mathrm{kg}$ of fillets and 151 tons of trimmings.

In option 2, 20\% of the production is sold as whole fish, $50 \%$ is filleted and $30 \%$ as smoked fillet. Investment costs increase by $15 \%$ to $6900 \mathrm{EUR} / \mathrm{m}^{3} \mathrm{PV}$ (2.07 mil. EUR) due to the slaughtering, cooling and smoking plant. Filleting and smoking lead to an additional need of 3.91 workers/year and therefore additional costs of 112,156 EUR/year. Water costs increase by $10 \%$ and electricity costs by $15 \% .64,058 \mathrm{~kg}$ of whole fish, $65,659 \mathrm{~kg}$ of fillets, $39,395 \mathrm{~kg}$ of smoked fillets and 151,176 kg of trimmings are produced annually.

Option 3 extends option 2 by a farm store for direct sales to final customers. The investment costs increase by another $20 \%$ to $8280 \mathrm{EUR} / \mathrm{m}^{3} \mathrm{PV}$ ( 2.48 mil. EUR) due to the construction of a farm store including fish counter and refrigeration. In the farm store, 1.50 salesmen/year are hired for 54,250 EUR/year. Gas, electricity and water costs increase by 
a further $10 \%$. Management and administration costs increase by $50 \%$ due to increased administrative demands. Of the production, $75 \%$ is sold to wholesalers and retailers and $25 \%$ is sold directly in the farm store. In the farm store, a $75 \%$ mark-up generates sales prices of 3.85 EUR/ $\mathrm{kg}$ (whole fish), $11.38 \mathrm{EUR} / \mathrm{kg}$ (fillet) and 21.88 EUR/ kg (smoked fillet).

\subsection{Calculations}

The calculations were performed using Microsoft Excel ${ }^{\circledR}[66]$, with all different costs in a single output sheet. This software was chosen because, besides its simplicity, it has been used effectively for economic calculations [67]. The enterprise budget was designed to provide economic assistance to existing plant operators and companies interested in building a catfish RAS. Existing plant operators can transfer their present values and, by adjusting individual variables, evaluate which parameters need to be changed in order to maximise returns. People interested in building a RAS can find out whether the construction of a plant can be profitable under given location factors. To calculate the different entrepreneurial decision scenarios, the new values were calculated in a separate sheet and the resulting values were transferred into a separate output file. For the respective entrepreneurial decision scenarios, the formulas were adapted in each case in separate sheets. For all scenarios, the respective business figures were transferred to a separate file and used to create the related tables.

For the calculation of the return on investment (ROI) of the aquaculture units, the operating result was divided by the capital employed (net investment minus $49 \%$ subsidies), as Mecklenburg-Western Pomerania and the European Fisheries Fund (EFF) and the European Maritime and Fisheries Fund (EMFF) supported the investors with subsidies amounting to $49 \%$ of the net expenses [29] (see above). The EMFF is replaced by the European Maritime Fisheries and Aquaculture Fund (EMFAF) in 2021, which subsidises sustainable aquaculture investments up to 50\% until 2027 [68]. The greenhouses of the aquaponic extension are subsidised by $20 \%$ through the agricultural investment promotion program of Mecklenburg-Western Pomerania (AFP: Agrarinvestitionsförderungsprogramm) [69].

\section{Results}

\subsection{Initial Model}

In the initial model (Table 1), the catfish farm does not generate profits, but the output based on realistic current market prices is sufficient to cover all costs. Additional benefits such as the CHP bonus, EEG reallocation charge and integration benefits into the own farming practices have not been evaluated and do not account for the aquaculture activity. The main cost driver of variable costs in the initial model is feed with a proportion of $61.42 \%$ of variable costs and $42.14 \%$ of total costs. At great distance follow the costs of energy $(12.23 \% ; 8.39 \%)$, followed by fingerlings $(9.94 \% ; 6.82 \%)$, wages $(8.22 \% ; 5.64 \%)$ and water $(5.10 \% ; 3.50 \%)$. Depreciation accounts for $22.06 \%$ of total costs. 
Table 1. Yearly revenues and costs of the initial model of an African catfish farm with $300 \mathrm{~m}^{3}$ production volume with a max stocking density of $450 \mathrm{~kg} / \mathrm{m}^{3}$ (average $180 \mathrm{~kg} / \mathrm{m}^{3}$ ) and an output of 320,288 kg/year.

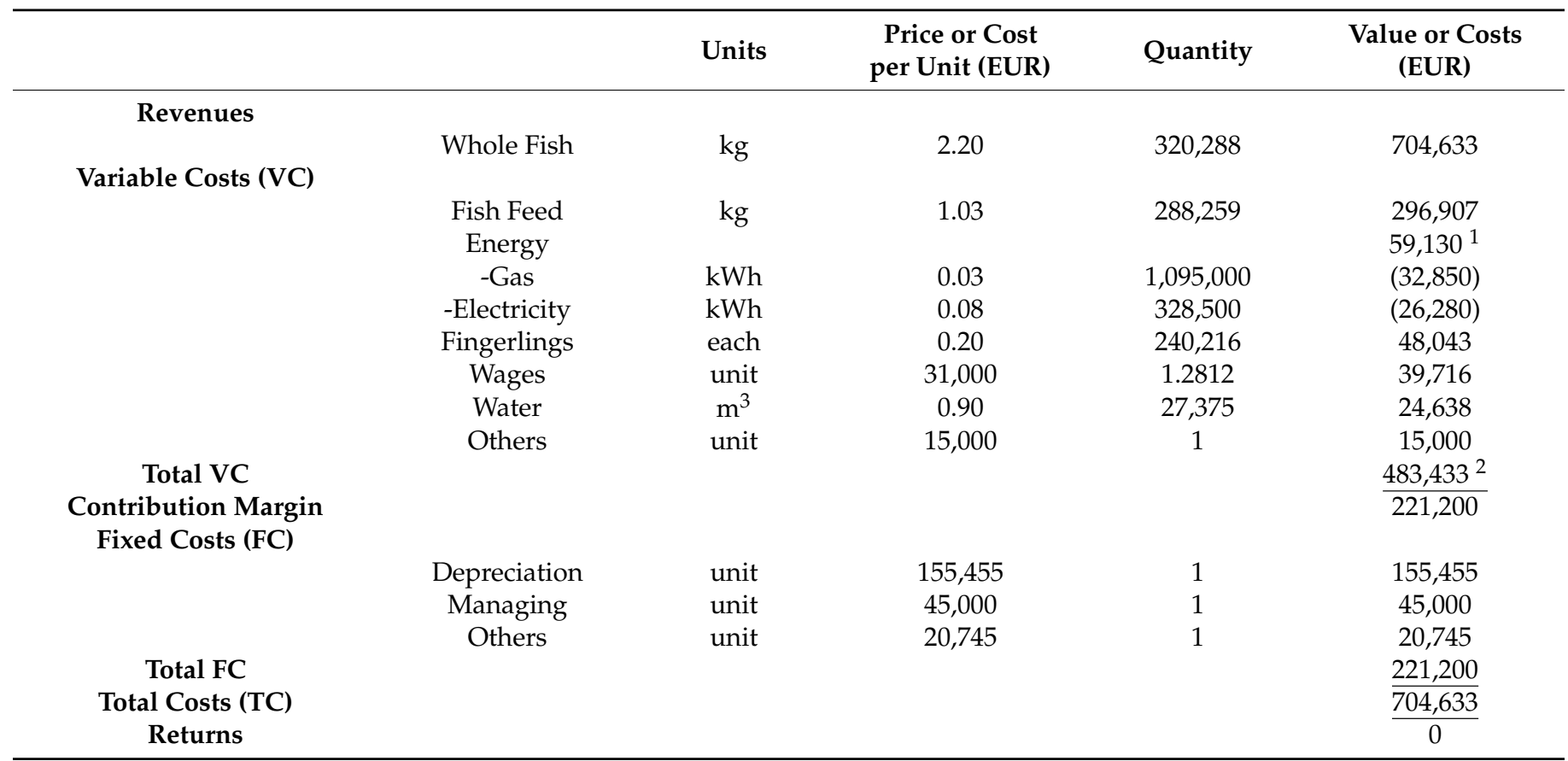

${ }^{1}$ Energy is the sum of Gas and Electricity. ${ }^{2}$ Underlines denote the sum of the respective costs.

\subsection{Change in Costs and Prices}

Among the main variable input factors, a change in feed has the highest impact on the key performance indicators (KPI) (Tables 2 and 3). Each ten percent change of $\pm 0.103 \mathrm{EUR} / \mathrm{kg}$ feed changes the returns by $\pm 29.691 \mathrm{EUR} /$ year, the ROI by $\pm 3.23 \%$ and the profit per $\mathrm{kg}$ of output produced by $\pm 0.093 \mathrm{EUR} / \mathrm{kg}$. The percentage deviations of the KPI from the initial model are $\pm 13.42 \%$ for the contribution margin (initial model: 221,200 EUR/year; $0.691 \mathrm{EUR} / \mathrm{kg}$; new value: EUR/year; $0.783 \mathrm{EUR} / \mathrm{kg}), \pm 6.14 \%$ for variable costs (483,433 EUR/year; $1.509 \mathrm{EUR} / \mathrm{kg}$ ) and $\pm 4.21 \%$ for total costs (704,633 EUR/year; 2.200 EUR/ $/ \mathrm{kg}$ ). The second largest impact among the variable input factors on the changes in KPI (Table 2) is a change in energy costs. However, relative to feed, the influence of an equal percentage change in energy prices is $80 \%$ less, or the influence of energy is $20 \%$ of the influence of feed. In third place are fingerlings, which have an $84 \%$ lower influence on the KPI changes in relation to feed, followed by wages with an $87 \%$ lower influence. In last place among the variable main input factors is water with a $92 \%$ lower influence, or with only $8 \%$ of the influence of feed. The fixed costs are mainly determined by the depreciation, i.e., by the investment costs $\left(\mathrm{EUR} / \mathrm{m}^{3} \mathrm{PV}\right)$. Each ten percent change $\left( \pm 600 \mathrm{EUR} / \mathrm{m}^{3} \mathrm{PV}\right.$ ) changes the investment costs of the initial model by $\pm 180,000 \mathrm{EUR}$ and thus the depreciation and at the same time the returns by $\pm 15,546 \mathrm{EUR} /$ year. ROI changes by $\pm 1.88 \%$, profit by \pm 0.049 EUR $/ \mathrm{kg}$ and total costs by $\pm 2.21 \%$. Compared with feed, the impact on the changes in Table 2 is thus $48 \%$ lower for each equal-percentage change in investment costs. In the case of ROI, the impact is only $42 \%$ lower due to the exclusion of subsidies. Contribution margin and variable costs remain unaffected by changes in fixed costs. The biggest impact on the profitability is a change in the selling price. Each ten percent change $( \pm 0.220 \mathrm{EUR} / \mathrm{kg})$ causes a change in revenue of $\pm 70,463 \mathrm{EUR} /$ year, ROI of $\pm 7.68 \%$, profit/output of $\pm 0.220 \mathrm{EUR} / \mathrm{kg}$ and contribution margin of $\pm 31.86 \%$. Thus, the impact of the selling price on the changes in the KPI is 137\% higher than that of feed. Water compared to selling price has a nearly $97 \%$ lower impact for each equal percent change. Total and variable costs remain unchanged. 


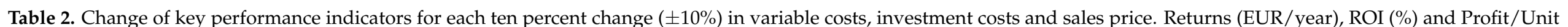

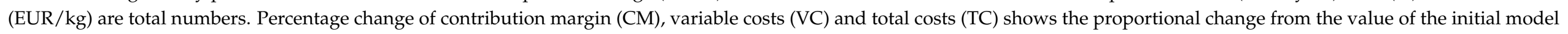
(EUR/year and EUR/unit).

\begin{tabular}{|c|c|c|c|c|c|c|c|c|}
\hline & Unit & $\begin{array}{l}\text { Change of Price or } \\
\text { Cost/Unit (EUR) }\end{array}$ & $\begin{array}{l}\text { Returns per Year } \\
\text { (EUR/year) }\end{array}$ & ROI ${ }^{1}$ Total (\%) & $\begin{array}{l}\text { Profit per kg Fish } \\
\text { (EUR/kg) }\end{array}$ & $\begin{array}{c}\text { Percentage Change } \\
\text { of CM }(\%)\end{array}$ & $\begin{array}{c}\text { Percentage } \\
\text { Change of VC }(\%)\end{array}$ & $\begin{array}{c}\text { Percentage } \\
\text { Change of TC }(\%)\end{array}$ \\
\hline Feed & $\mathrm{kg}$ & \pm 0.103 & $\pm 29,691$ & \pm 3.23 & \pm 0.093 & \pm 13.42 & \pm 6.14 & \pm 4.21 \\
\hline Energy (Total) & & & \pm 5913 & \pm 0.64 & \pm 0.018 & \pm 2.67 & \pm 1.22 & \pm 0.84 \\
\hline -Electricity & $\mathrm{kWh}$ & \pm 0.008 & \pm 2628 & \pm 0.29 & \pm 0.008 & \pm 1.19 & \pm 0.54 & \pm 0.37 \\
\hline Fingerlings & ea. & \pm 0.020 & \pm 4804 & \pm 0.52 & \pm 0.015 & \pm 2.17 & \pm 0.99 & \pm 0.68 \\
\hline Wages & unit & \pm 3100 & \pm 3972 & \pm 0.43 & \pm 0.012 & \pm 1.80 & \pm 0.82 & \pm 0.56 \\
\hline Water & $\mathrm{m}^{3}$ & \pm 0.090 & \pm 2464 & \pm 0.27 & \pm 0.008 & \pm 1.11 & \pm 0.51 & \pm 0.35 \\
\hline Sales price & $\mathrm{kg}$ & \pm 0.220 & $\pm 70,463$ & \pm 7.68 & \pm 0.220 & \pm 31.86 & \pm 0.00 & \pm 0.00 \\
\hline
\end{tabular}

${ }^{1} \mathrm{ROI}=$ Return on Investment is calculated as returns/(investment-subsidy). Fisheries investments in Mecklenburg-Western Pomerania are subsidised at $49 \%$.

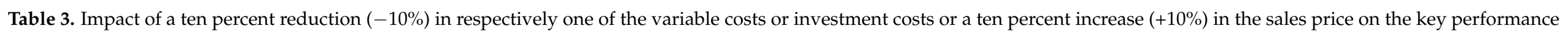
indicators (KPIs). The initial model is the calculation basis (CB) with annual returns of 0 EUR.

\begin{tabular}{|c|c|c|c|c|c|c|c|c|c|c|c|c|c|}
\hline & Unit & $\begin{array}{c}\text { New Price } \\
\text { or } \\
\text { Cost/Unit } \\
\text { (EUR) }\end{array}$ & $\begin{array}{c}\text { Ivestment } \\
\text { Cost (mil. } \\
\text { EUR) }\end{array}$ & $\begin{array}{c}\mathrm{CM}^{2} \text { per } \\
\text { year } \\
\text { (EUR/Year) }\end{array}$ & $\begin{array}{l}\text { Variable } \\
\text { Costs per } \\
\quad \text { Year } \\
\text { (EUR/year) }\end{array}$ & $\begin{array}{c}\text { Fixed } \\
\text { Costs per } \\
\quad \text { Year } \\
\text { (EUR/Year) }\end{array}$ & $\begin{array}{c}\text { Revenues } \\
\text { per Year } \\
\text { (EUR/Year) }\end{array}$ & $\begin{array}{l}\text { Returns } \\
\text { per Year } \\
\text { (EUR/Year) }\end{array}$ & $\underset{(\%)}{\text { ROI }^{1}}$ & $\begin{array}{l}\mathrm{CM}^{2} \text { per } \\
\text { kg Fish } \\
(\text { EUR/kg) }\end{array}$ & $\begin{array}{c}\text { Variable } \\
\text { Costs per } \\
\text { kg Fish } \\
\text { (EUR/kg) }\end{array}$ & $\begin{array}{c}\text { Total } \\
\text { Costs per } \\
\text { kg Fish } \\
\text { (EUR/kg) }\end{array}$ & $\begin{array}{c}\text { Profit per } \\
\text { kg Fish } \\
\text { (EUR/kg) }\end{array}$ \\
\hline Feed & $\mathrm{kg}$ & 0.927 & 1.80 & 250,890 & 453,742 & 221,200 & 704,633 & 29,691 & 3.23 & 0.783 & 1.417 & 2.107 & 0.093 \\
\hline Energy (Total) & & & 1.80 & 227,113 & 477,520 & 221,200 & 704,633 & 5913 & 0.64 & 0.709 & 1.491 & 2.182 & 0.018 \\
\hline -Gas & kWh & 0.027 & 1.80 & 224,485 & 480,148 & 221,200 & 704,633 & 3285 & 0.36 & 0.701 & 1.499 & 2.190 & 0.010 \\
\hline -Electricity & kWh & 0.072 & 1.80 & 223,828 & 480,805 & 221,200 & 704,633 & 2628 & 0.29 & 0.699 & 1.501 & 2.192 & 0.008 \\
\hline Fingerlings & each & 0.180 & 1.80 & 226,004 & 478,628 & 221,200 & 704,633 & 4804 & 0.52 & 0.706 & 1.494 & 2.185 & 0.015 \\
\hline Wages & unit & 27,900 & 1.80 & 225,171 & 479,461 & 221,200 & 704,633 & 3972 & 0.43 & 0.703 & 1.497 & 2.188 & 0.012 \\
\hline Water & $\mathrm{m}^{3}$ & 0.810 & 1.80 & 223,663 & 480,969 & 221,200 & 704,633 & 2464 & 0.27 & 0.698 & 1.502 & 2.192 & 0.008 \\
\hline Invest. costs & $\mathrm{m}^{3} \mathrm{PV}$ & 5400 & 1.62 & 221,200 & 483,433 & 205,654 & 704,633 & 15,546 & 1.88 & 0.691 & 1.509 & 2.151 & 0.049 \\
\hline Sales price & $\mathrm{kg}$ & 2.420 & 1.80 & 291,636 & 483,433 & 221,200 & 775,096 & 70,463 & 7.68 & 0.911 & 1.509 & 2.200 & 0.220 \\
\hline
\end{tabular}

${ }^{1} \mathrm{ROI}=$ Return on Investment is calculated as returns $/$ (investment-subsidy). Fisheries investments in Mecklenburg-Western Pomerania are subsidised at $49 \% .{ }^{2} \mathrm{CM}=\mathrm{Contribution} \mathrm{Margin.}$ 


\subsection{Entrepreneural Decision Scenarios}

\subsubsection{Double Production Volume}

By doubling production from $300 \mathrm{~m}^{3}$ to $600 \mathrm{~m}^{3}$ production volume, the variable costs per unit (VCU) of the initial model is reduced by $7.6 \%$ from $1.509 \mathrm{EUR} / \mathrm{kg}$ to $1.395 \mathrm{EUR} / \mathrm{kg}$ and the total costs per unit (CPU) is reduced by $12.4 \%$ from $2.200 \mathrm{EUR} / \mathrm{kg}$ to $1.926 \mathrm{EUR} / \mathrm{kg}$ (Table 4). With double the output, the savings generate returns of 175,240 EUR/year (0.274 EUR $/ \mathrm{kg}$ fish) with an ROI of $11.45 \%$ (Table 5). A ten percent increase in the retail price of whole fish in this scenario results in an increase in returns and ROI of $80.4 \%$ (316,167 EUR/year; 20.66\%).

\subsubsection{Higher Stocking Densities}

The increase in max. stocking density from $450 \mathrm{~kg} / \mathrm{m}^{3}$ to $550 \mathrm{~kg} / \mathrm{m}^{3}$ (average stocking density $220 \mathrm{~kg} / \mathrm{m}^{3}$ ) slightly increases VCU by $1.5 \%$ to $1.532 \mathrm{EUR} / \mathrm{kg}$ and CPU is reduced by $4.7 \%$ (Table 4$)$. The $22 \%$ increase in output $(391,463 \mathrm{~kg} /$ year) generates returns of 40,379 EUR/year (0.10 EUR/ $\mathrm{kg}$ ) with an ROI of $4.40 \%$ (Table 5). In this scenario, a ten percent increase in the selling price leads to a $213.3 \%$ increase in returns and ROI (126,167 EUR/year; 13.78\%).

Table 4. Sales price, contribution margin per unit (CMU), variable costs per unit (VCU), total costs per unit (CPU) and profit per unit (PPU) of the respective products in the different scenarios.

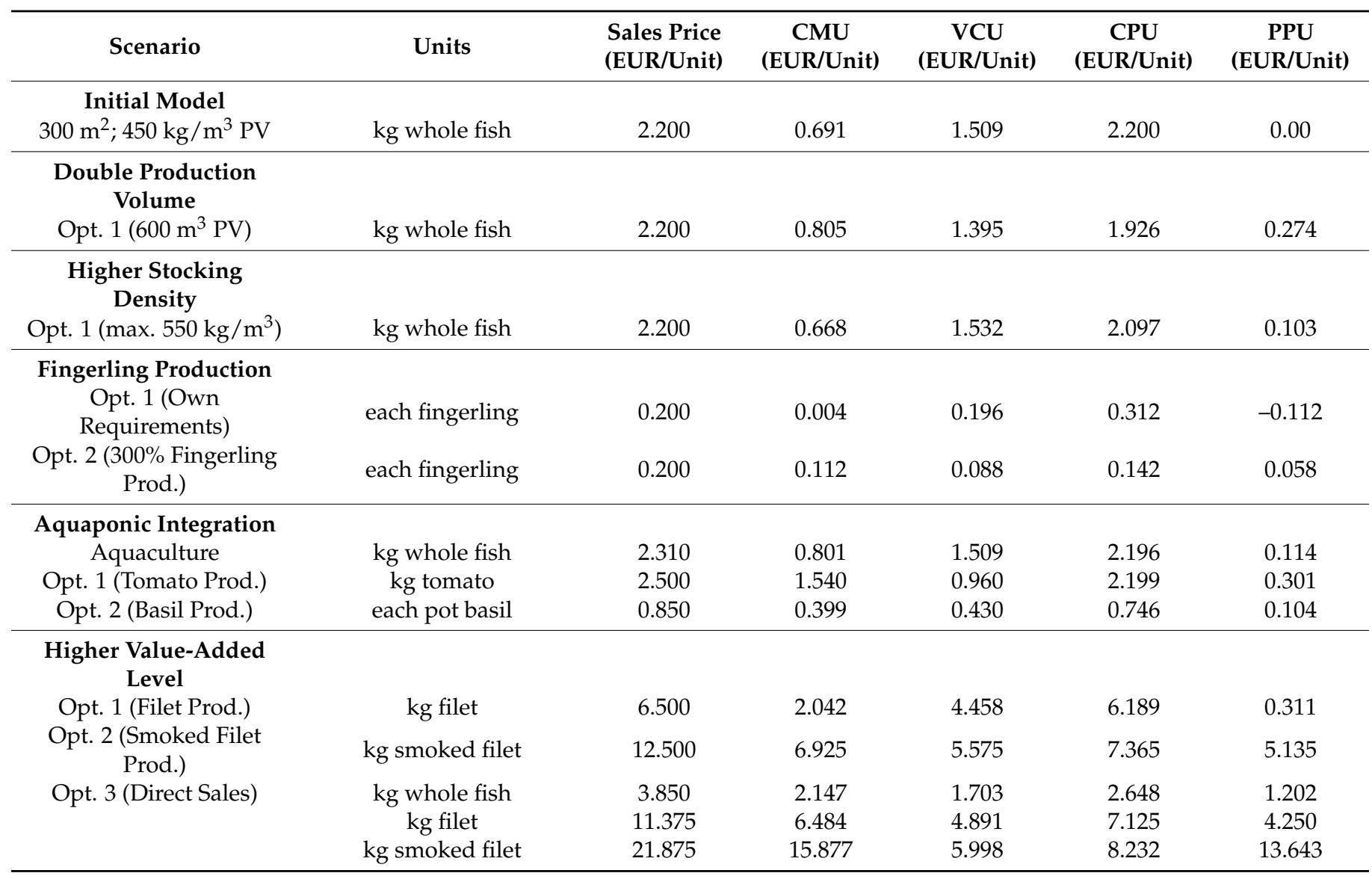

\subsubsection{Fingerling Production}

With fingerling production, in the case of exclusive self-supply (Opt. 1) of the farm (240,216 fingerlings/year), a fingerling has VCU of 0.196 EUR/each, CPU of 0.312 EUR/each and a PPU of $-0.112 \mathrm{EUR} /$ each (Table 4). Considered as a single investment, the fingerling production has an ROI of $-17.65 \%$. Despite the elimination of fingerlings costs, 
the excessively high production costs result in negative returns of $-27,011 \mathrm{EUR} /$ year $(-0.08 \mathrm{EUR} / \mathrm{kg}$ ) with an ROI of $-2.33 \%$ (Table 5$)$. In option 2 , the farm produces $300 \%$ of its own needs (720,647 fingerlings/year) and resells $200 \%$. VCU are reduced by $55.3 \%$ to $0.088 \mathrm{EUR} /$ each, CPU decrease by $54.7 \%$ to $0.142 \mathrm{EUR} /$ each due to economies of scale (Table 4). Thus, at a selling price of 0.200 EUR/each, a saving, or PPU of 0.058 EUR/each can be achieved. Considered as a single investment, the hatchery has an ROI of $21.18 \%$. This results in returns of 34,684 EUR/year and an ROI of 3.11\% (Table 5). A ten percent increase in fingerling prices increases returns and ROI by $27.7 \%$ (44,293 EUR/year; 3,97\%).

Table 5. The impact of the different scenarios on the total investment costs (TIC), and yearly variable costs (VC), fixed costs (FC), revenues, returns and return on investment (ROI). In addition, the impact of a ten percent change $(+10 \%)$ in the sales price of the respective production unit on the key performance indicators in the respective scenarios is calculated. In case of price variations, TIC, VC and FC remain unchanged.

\begin{tabular}{|c|c|c|c|c|c|c|}
\hline Szenario & $\begin{array}{c}\text { TIC } \\
\text { (EUR) }\end{array}$ & $\begin{array}{c}\text { VC } \\
\text { (EUR/Year) }\end{array}$ & $\begin{array}{c}\text { FC } \\
\text { (EUR/Year) }\end{array}$ & $\begin{array}{l}\text { Revenues } \\
\text { (EUR/Year) }\end{array}$ & $\begin{array}{c}\text { Returns } \\
\text { (EUR/Year) }\end{array}$ & $\begin{array}{c}\text { ROI }^{1} \\
(\%)\end{array}$ \\
\hline $\begin{array}{c}\text { Initial Model } \\
300 \mathrm{~m}^{2} ; 450 \mathrm{~kg} / \mathrm{m}^{3} \mathrm{PV}\end{array}$ & $1,800,000$ & 483,432 & 221,199 & 704,632 & 0.00 & $0.00 \%$ \\
\hline $\begin{array}{l}\text { Double Production } \\
\text { Volume } \\
\text { Opt. } 1\left(600 \mathrm{~m}^{3} \mathrm{PV}\right) \\
+10 \% \text { Fish Price }\end{array}$ & $3,000,000$ & 893,630 & 340,395 & $\begin{array}{l}1,409,265 \\
1,550,192\end{array}$ & $\begin{array}{l}175,240 \\
316,167\end{array}$ & $\begin{array}{l}11.45 \% \\
20.66 \%\end{array}$ \\
\hline $\begin{array}{c}\text { Higher Stocking Density } \\
\text { Opt. } 1(\max . \\
\left.550 \mathrm{~kg} / \mathrm{m}^{3} \mathrm{PV}\right) \\
+10 \% \text { Fish Price }\end{array}$ & $1,800,000$ & 599,639 & 221,200 & $\begin{array}{l}861,218 \\
947,339\end{array}$ & $\begin{array}{r}40,379 \\
126,501\end{array}$ & $\begin{array}{r}4.40 \% \\
13.78 \%\end{array}$ \\
\hline $\begin{array}{c}\text { Fingerling Production } \\
\text { Opt. } 1 \text { (Own Production) } \\
\text { Opt. } 2 \text { (300 \% Fingerling } \\
\text { Prod.) } \\
+10 \% \text { Fingerling Price }\end{array}$ & $\begin{array}{l}2,100,000 \\
2,190,000\end{array}$ & $\begin{array}{l}482,460 \\
505,967\end{array}$ & $\begin{array}{l}249,183 \\
260,068\end{array}$ & $\begin{array}{l}704,633 \\
800,719 \\
810,327\end{array}$ & $\begin{array}{c}-27,011 \\
34,684 \\
44,293\end{array}$ & $\begin{array}{l}-2.52 \% \\
3.11 \% \\
3.97 \%\end{array}$ \\
\hline $\begin{array}{l}\text { Aquaponic Integration } \\
\text { Aquaculture } \\
\text { Opt. } 1 \text { (1000 } \mathrm{m}^{2} \text { Tomatoes) } \\
\text { Total Aquaponic } \\
+10 \% \text { Tomato Price } \\
\text { Total Aquaponic } \\
\text { Opt. } 2\left(10,000 \mathrm{~m}^{2} \text { Basil }\right) \\
\text { Total Aquaponic } \\
+10 \% \text { Basil Price } \\
\text { Total Aquaponic }\end{array}$ & $\begin{array}{c}1,890,000 \\
509,548 \\
2,399,548\end{array}$ & $\begin{array}{c}483,433 \\
50,880 \\
534,313\end{array}$ & $\begin{array}{c}219,972 \\
65,690 \\
285,662\end{array}$ & $\begin{array}{c}739,864 \\
132,500 \\
872,364 \\
145,750 \\
885,614 \\
2,018,750 \\
2,758,614 \\
2,220,625 \\
2,960,489\end{array}$ & $\begin{array}{c}36,459 \\
15,930 \\
52,389 \\
29,180 \\
65,639 \\
248,043 \\
284,502 \\
449,918 \\
486,377\end{array}$ & $\begin{array}{c}3.78 \% \\
3.91 \% \\
3.82 \% \\
7.16 \% \\
4.79 \% \\
6.93 \% \\
6.26 \% \\
12.57 \% \\
10.70 \%\end{array}$ \\
\hline $\begin{array}{c}\text { Higher Value-Added } \\
\text { Level } \\
\text { Opt. } 1 \text { ( } 80 \% \text { Filet) } \\
+10 \% \text { Filet Price }\end{array}$ & $1,980,000$ & 566,065 & 236,745 & $\begin{array}{l}831,338 \\
899,624\end{array}$ & $\begin{array}{l}28,529 \\
96,814\end{array}$ & $\begin{array}{l}2.83 \% \\
9.59 \%\end{array}$ \\
\hline $\begin{array}{c}\text { Opt. } 2 \text { (30\% Smoked Filet, } \\
\text { 80\% Filet) } \\
+10 \% \text { Smoked Filet Price } \\
\text { Opt. } 3 \text { (Direct Sales) } \\
+10 \% \text { Direct Sales Price }\end{array}$ & $2,070,000$ & 610,995 & 244,518 & $\begin{array}{l}1,067,710 \\
1,116,955 \\
1,266,489 \\
1,312,870\end{array}$ & $\begin{array}{l}212,198 \\
261,442 \\
297,204 \\
343,586\end{array}$ & $\begin{array}{l}20.10 \% \\
24.76 \% \\
23.46 \% \\
27.12 \%\end{array}$ \\
\hline
\end{tabular}

${ }^{1} \mathrm{ROI}=$ Return on Investment is calculated as returns / (investment-subsidy). Fisheries investments in Mecklenburg-Western Pomerania are subsidised at $49 \%$ and agricultural investments (aquaponic integration option 1 and 2 ) at $20 \%$.

\subsubsection{Aquaponic Integration}

Due to the aquaponic integration, the VCU in the fish farm remain unchanged, the CPU decrease minimally by $0.2 \%$ (Table 4 ). Due to the increased sales price of the aquaponically distributed fish, fish farm returns increase to 36,459 EUR/year $(0.114 \mathrm{EUR} / \mathrm{kg})$ and 
ROI increases to $3.78 \%$ (Table 5). In option 1, the tomato greenhouse generates returns of $15,930 \mathrm{EUR} /$ year (0.301 EUR/kg tomato) and an ROI of 3.91\%. Fish and plant farming considered as a single aquaponics enterprise generate returns of 52,389 EUR/year and an ROI of $3.82 \%$. A $10 \%$ increase in tomato prices increases returns and ROI of the greenhouse by $83.2 \%(29,180 \mathrm{EUR} /$ year; $7.16 \%)$ and of the aquaponic enterprise by $25.3 \%$ $(65,639 \mathrm{EUR} /$ year; $4.79 \%)$. In option 2 , the large $10,000 \mathrm{~m}^{2}$ basil greenhouse generates returns of 248,043 EUR/year (0.10 EUR/pot) and an ROI of 10.87\%. Together with fish farming, this results in returns of $284,502 \mathrm{EUR} /$ year and an ROI of $8.76 \%$. A ten percent increase in basil prices increases returns and ROI of the greenhouse by $81.4 \%(449,918$ EUR/year; $12.57 \%)$ and of the aquaponic farm by $71.0 \%$ (486,377 EUR/year; $10.70 \%)$.

\subsubsection{Higher Value-Added Level}

In option $1,80 \%$ of the production is filleted and $20 \%$ is sold as whole fish. The $20 \%$ whole fish $(64,058 \mathrm{~kg}$ /year) returns 140,927 EUR/year. With a fillet yield of $41 \%$, $105,054 \mathrm{~kg} /$ year of fillet are produced and generate $682,853 \mathrm{EUR} /$ year. In addition, the trimmings (151 tons) contribute 7559 EUR/year, if sold outside. Possible internal use on the farms has not been considered. The total revenue of 831,338 EUR/year results in returns of $28.529 \mathrm{EUR} /$ year and an ROI of 2.83\% (Table 5). A ten percent increase in fillet price increases the two KPIs by $239.4 \%$ (96,814 EUR/year; $9.59 \%)$. Labour costs in this scenario increase by $195.2 \%$ to $127,027 \mathrm{EUR} /$ year, with a total costs share (TC) of $15.82 \%$ (22.44\% VC).

In option 2 (20\% whole fish, 50\% fillet, 30\% smoked fillet), the $20 \%$ whole fish and the 151 tons of trimmings continue to generate 140,927 EUR/year and 7559 EUR/year, respectively. The $50 \%$ fillets $(65,659 \mathrm{~kg} /$ year) generate $426,783 \mathrm{EUR} /$ year and the $30 \%$ smoked fillets $(39,395 \mathrm{~kg} /$ year $) 492,442 \mathrm{EUR} /$ year. The total revenue of 1,069,710 EUR/year leads to returns of $212,198 \mathrm{EUR} /$ year with an ROI of $20.10 \%$. If the smoked fillet price increase by $10 \%$, both KPIs increase by $23.2 \%$ (261,442 EUR/year; $24.76 \%$ ). In this scenario, labour costs increase by $423.6 \%$ compared to the initial model to $168,220 \mathrm{EUR} / \mathrm{year}$ with a significantly higher TC share of $19.66 \%$ (27.53\% VC).

Option 3 extends option 2 with direct marketing to end consumers ( $25 \%$ of production). The marketing of $75 \%$ of the production to wholesalers and retailers generates revenues of 802,673 EUR/year. The 25\% direct marketing, with selling prices of $3.85 \mathrm{EUR} / \mathrm{kg}$ (whole fish), 11.38 EUR/kg (fillet) and 21.88 EUR/ kg (smoked fillet), generate 463,816 EUR/year, almost $37 \%$ of the 1,266,489 EUR/year total revenue. In total, returns of 297,204 EUR/year and an $\mathrm{ROI}$ of $23.46 \%$ are realised. A ten percent increase in prices in the direct marketing makes the two key figures rise by $15.6 \%$ (343,586 EUR/year; $27.12 \%)$. Labour costs increase by $440.6 \%$ to $214,720 \mathrm{EUR} /$ year, ranking clearly behind feed and before energy costs with a TC share of $22.15 \%(32.22 \% \mathrm{VC})$.

\section{Discussion}

The present study calculates the cost structure of African catfish RAS in northern Germany based on a model farm and current market conditions. The northern German catfish aquaculture is a very young industry, which was indirectly initiated by the European Commission through the EFF 2007-2013 and EMFF 2014-2021. Subsidised fishery investments at $49 \%$ motivated farmers to enter this new sector. Along with the additional benefits of an internal use of the electricity and heat from own biogas plants, the integration into regular farming practices, the ecological sustainability of production and the $\mathrm{CHP}$ bonus and EEG reallocation charge, an investment in heat-utilising catfish RAS is particularly attractive. However, under the current economic market conditions for a less established fish species and due to management and fish disease-related production stoppages/shortages, the northern German catfish farms have not yet managed to achieve the promised long-term operating results. In the following, the effects of price variations and different entrepreneurial decision scenarios on key performance indicators of German catfish farms are listed and discussed. 


\subsection{Initial Model with Price Variation}

An average African catfish RAS (recirculating aquaculture system) with a production volume of $300 \mathrm{~m}^{3}$ and an output of $320 \mathrm{t} /$ year can cover all costs, but has difficulties to reach profitably (Table 1) without consideration of additional benefits (see above). The most important economic variable in African catfish RAS is the low selling price, caused by a less established market environment for this relatively unknown species. If the average selling price $(2.20 \mathrm{EUR} / \mathrm{kg})$ changes by $10 \%$, the returns change by $\pm 70,463 \mathrm{EUR} /$ year (Table 2). The average selling price and the total production costs of $2.20 \mathrm{EUR} / \mathrm{kg}$ as well as the variable costs of $1,51 \mathrm{EUR} / \mathrm{kg}$ can be considered as critical prices. For catfish (Ictalurus furcatus $\times$ Ictalurus punctatus) split-pond aquaculture in Arkansas and Mississippi, critical price thresholds are lower with a range of $1.72-2.05 \mathrm{USD} / \mathrm{kg}$ [70] due to cheaper production in pond aquaculture and not RAS. Production costs in areas where African catfish are most economically cultivated vary from $<1 \mathrm{USD} / \mathrm{kg}$ to $2.5 \mathrm{USD} / \mathrm{kg}$ [14]. The selling prices of living African catfish in sub-Saharan Africa (2.5-5.0 USD $/ \mathrm{kg}$ ), alternatively Central Africa (3.3-5.2 USD $/ \mathrm{kg}$ ) or Nigeria (3.5 USD $/ \mathrm{kg}$ ) [14], demonstrate clearly that $2.20 \mathrm{EUR} / \mathrm{kg}$ in Germany is very low for regionally produced high valuable animal proteins [23] and African catfish still has a lot of marketing potential.

In northern Germany, most of the production is sold as whole fish to wholesalers, whereby far the lowest returns are achieved compared to retail and direct marketing. The difficulty of selling larger quantities to retailers is that catfish farms are located in the most sparsely populated, agriculturally dominated regions of northern Germany, with a low incidence of retail trade. This makes it more difficult to distribute larger quantities on better price conditions. Nevertheless, the focus of the plant operators should be to build upon more retail contract partners. Slightly higher selling prices already cover the increased transportation costs and labour hours. When selling to retailers, it is important to ensure that the contractually agreed purchase quantities are adhered, otherwise there is a risk of contractual penalties. A general prognosis regarding African catfish prices is difficult to make. However, there are studies that predict a decrease in animal protein consumption and an increase especially in fish and seafood substitutes in Europe [71]. Annual per capita consumption of fish and fishery products in Germany also decreased by $19 \%$ from $2011(15.7 \mathrm{~kg})$ to $2019(13.2 \mathrm{~kg})$ [72]. After a slight increase in 2020, further decrease in consumption is predicted by 2022 [73]. From 2021 to 2026, the industry's revenue is expected to increase by $1.2 \%$ /year and the average price of fish and fishery products is expected to increase by $11.3 \%$ over the entire period [73]. These values indicate the trend direction of the German fish industry but a full extrapolation to the northern German catfish market cannot be made.

Fish feed accounts for $42.14 \%$ of the TC (total costs) and $61.42 \%$ of VC (variable costs), which is similar to catfish split-pond aquaculture in Arkansas and Mississippi, where feed accounts for $47-56 \%$ TC (54-61\% VC) [70]. The returns change by $\pm 29,691$ EUR/year for each ten percent change in purchase prices (Table 2). In Nigerian pond culture, feed costs average $64 \%$ of TC [74], while in Thai and Vietnamese Pangasius pond culture feed costs reach $81 \%$ and $86 \%$ of TC [75], respectively, making them even more sensitive to price changes. This difference is caused by a different degree of investment costs, which is higher in RAS operations compared with pond aquaculture. Catfish feed has a protein content of at least $40 \%$ with the majority coming from fish meal. While the demand for fish meal increased, its production decreased by $26.5 \%$ from 2000-2018 due to climatic events, resulting in a price increase during the same period from $452 \mathrm{USD} / \mathrm{t}$ to $1597 \mathrm{USD} / \mathrm{t}$ [76]. Occasionally, C. gariepinus growers had to close their operations as high production costs exceeded the selling prices due to high feed costs [14]. In order to compensate for the resulting increase in the price of fish feed, catfish farmers must be in a position to pass on the price increases to their customers or to secure long-term price commitments from suppliers by contract. In addition, researchers and farm operators need to continue research on plant-based fish meal substitutes that are accepted by catfish and achieve better growth performance. The declining fish-in/fish-out ratio from 0.63 in 2000 via 0.33 (2010) through 
to 0.22 (2015) shows the resilience of the sector for fish meal replacement [76]. It was also demonstrated that a feed additive of $0.5 \% 1 \mathrm{~g} 557$ to regular African catfish feed already resulted in a $2 \%(0.8-3.2 \%)$ better growth performance of juveniles, raising the returns by 4367 EUR/year including extra costs [77]. This suggests high potentials for the further development of more adequate African catfish feed in future.

The investment costs per $\mathrm{m}^{3}$ of production volume are largely determined by the farm size, structural conditions and degree of mechanisation and influence the annual operating result through depreciation. With a share of $22.06 \%$ of $\mathrm{TC}$, each ten percent variation changes the returns by $\pm 15,546$ EUR/year. The catfish split-ponds in North America have very low depreciation shares of 3-6\% of TC due to lower investment costs, but also have considerably more inefficient production at FCRs of 1.8-2.6 [70] compared with the northern German RAS averaging FCRs of 0.9. Energy costs are far behind feed costs, accounting for $8.39 \%$ of TC (12.23\% VC). Every ten percent change in gas and electricity prices changes the returns by \pm 5913 EUR/year (Table 2). Since the farmers in northern Germany produce electricity and waste heat through their own biogas plants, future increases in energy costs are not considered critical. In general, the principle of on-site supply with renewable energies is not only more sustainable, but also more cost-efficient than fossil-based fuels and thus of potential use to RAS [78]. In addition, the new government elected in 2021 will promote the expansion of renewable energies [79], which makes new subsidies for biogas plants with utilisation of waste heat in the upcoming years likely. Fingerlings account for $6.82 \%$ of TC (9.94\% VC) and result in a change in returns of $\pm 4804 \mathrm{EUR} /$ year for each ten percent price change. In Cameroon (0.15-0.25 USD/each) or Nigeria (0.1-0.2 USD/each), prices are also high due to high demand, causing many farmers to prefer collecting wild seed with poor growth performance [14]. In terms of cost, this variable is considered less critical for German farmers, but nevertheless a part of the production is still dependent on fingerlings from the Netherlands. In the case of supply shortages of Dutch producers, it can be assumed that Dutch bulk buyers will be preferred over the northern German catfish farms, which could lead to production bottlenecks. This could in turn jeopardise the supply of customers in the lucrative retail trade due to contractual quantities that cannot be met. In order to be less dependent on foreign suppliers, a stable regional catfish hatchery producing high quality fingerlings must be established in the medium term.

Wages represent $5.64 \%$ of TC $(8.22 \%$ VC) for a highly mechanised plant without hand slaughtering. Each ten percent price variation changes the returns by $\pm 3972 \mathrm{EUR} /$ year. In the case of internal hand slaughtering and filleting or a lower level of automation, labor costs increase and they should be considered in more detail. Since mainly unskilled labor is hired for repetitive tasks, payments at or slightly above statutory minimum wage are common. In this context, it should be noted that Germany is planning a successive increase in minimum wages in the coming years, especially with the new government $[80,81]$. Above a certain labor wage, it may be reasonable to dispense with hand slaughtering and outsource this activity or to invest into a filleting machine. Water costs amount to $3.50 \%$ of TC $(5.10 \% \mathrm{VC})$ and change returns by $\pm 2464 \mathrm{EUR} /$ year for each ten percent change. Since all northern German catfish RAS already have their own wells for industrial water production, further costs can be saved by reducing the price of drinking water and wastewater. The price of drinking water can hardly be influenced and depends on regional conditions and internal consumption in sanitary facilities and slaughtering. Wastewater costs, on the other hand, can be reduced by irrigation on own fields or by further use in hydroponic cultivations (aquaponics).

The list demonstrates that the main focus for African catfish farmers in northern Germany must be on improving sales prices and reducing feed costs in order to run the RAS profitably. The ROI shows that despite the deduction of subsidies only in the scenario of a price increase the ROI already reaches an attractive value (7.86\%). Although there are economically more interesting investment objects, from the sustainability perspective and in the light of the current climatic development, regional food production in Europe is to be evaluated as an indispensable future supply model. For this reason, the EMFF, which 
expired in 2020, was replaced in 2021 by the EMFAF (European Maritime, Fisheries and Aquaculture Fund) [68], which runs until 2027. This will continue to support aquaculture projects at $50 \%$, allowing investments to remain attractive under the right conditions. In addition, it aims to support and form "producer organisations". A producer organisation in northern Germany for the joint creation of synergies and utilisation of resources is assessed as imperative. Thus, joint bulk purchase deals for feed could be closed in order to significantly reduce costs and also to develop an own feed production in the long term. Furthermore, a regional fingerling hatchery could be created in order to produce the entire regional demand cost-efficiently and to achieve independence from Dutch suppliers. In addition, know-how could be exchanged and human resources shared, or investments could be made in jointly used machinery and equipment such as a filleting machine. Furthermore, larger contracts with retail chains could be concluded jointly, as it would be easier to meet contractually agreed purchase quantities at agreed times. This would result in a significant price increase. Moreover, investments could be made in marketing campaigns that increase the image and popularity of the African catfish, thus increasing its demand and sales price. For the establishment, the competitive thinking of the individual actors and personal interests must be overcome, and action plans must be drawn up together with research institutions.

\subsection{Entrepreneurial Decision Scenarios}

Entrepreneurial decision scenarios on the economics of catfish aquaculture are analysed in order to envision future potential for this industry. A RAS twice as large $\left(600 \mathrm{~m}^{3}\right.$ $\mathrm{PV})$ as in the initial model $\left(300 \mathrm{~m}^{3} \mathrm{PV}\right)$ is modelled, which saves costs through economies of scale. In a large plant, the fish can be produced at lower CPU $1.926 \mathrm{EUR} / \mathrm{kg}$ and VCU $1.395 \mathrm{EUR} / \mathrm{kg}$ which enhance the PPU to $0.274 \mathrm{EUR} / \mathrm{kg}$ (Table 4). Returns of 175,240 EUR/year and an ROI of $11.45 \%$ are achieved (Table 5). With a $10 \%$ increase in the catfish price to $2.42 \mathrm{EUR} / \mathrm{kg}$, returns and ROI increase by $80.4 \%$ (316,167 EUR/year; $20.66 \%$ ) and would transform a catfish RAS into an attractive investment. A model study of the profitability of U.S. pond, raceway, and RAS aquaculture showed that RAS systems were not profitable at any size or with any species, but larger systems showed fewer losses (in USD $/ \mathrm{kg}$ ) than smaller systems [32]. The study found economies of scale for all species/systems/sizes studied, which is consistent with observed trends of generally increasing farm size in aquaculture. The present results show that new investments into larger sized RAS are highly recommended in order to further develop the northern German catfish aquaculture into a profitable business sector. It is advisable to divide larger farms into two or more hygienically separated halls in order to avoid the loss of the entire stock in the event of a disease outbreak.

The scenario of increasing the maximum stocking densities from $450 \mathrm{~kg} / \mathrm{m}^{3}$ to $550 \mathrm{~kg} / \mathrm{m}^{3}$ increases the VCU slightly $(1.532 \mathrm{EUR} / \mathrm{kg})$ but decreases the CPU $(1.926 \mathrm{EUR} / \mathrm{kg})$ due to a better utilisation of the production capacities, thus achieving a PPU of $0.103 \mathrm{EUR} / \mathrm{kg}$ (Table 4). This results in returns of 40,379 EUR/year and an ROI of 4.40\% (Table 5). Although high stocking densities result in improved profitability, the likelihood of filter and pipe clogging and critical water levels being exceeded is increased. In addition, not all available feeds are suitable for RAS aquaculture and increase nutrient and total suspended matter loads and malfunctioning of biofilters. Therefore, more frequent water monitoring and filter cleaning must be carried out. High stocking densities also promote heterogeneous fish growth, resulting in uneven fillet sizes when slaughtered by hand and high discard rates when slaughtered by machine [20]. Mortality rates and also the FCR of African catfish in commercial RAS can slightly increase with increasing stocking density from extensive (FCR 0.96/0.87-1.14) to intensive (0.99/0.94-1.07) over the entire production cycle [9]. Superintensive stocking densities can be seen as questionable from an animal ethics point of view and can affect sales through negative publicity.

The entrepreneurial decision to produce own fingerlings is divided into two options. The first option of self-sufficiency is not recommended because the extra costs of 
the higher skilled employee and the investment costs for the hatchery are significantly higher than the savings. However, a hatchery can be profitable if production exceeds own requirements. Thus, by producing $300 \%$ of the own requirements (option 2 ), the CPU (0.141 EUR/each) and VCU (0.088 EUR/each) are approximately halved and the PPU improves from -0.090 EUR/each to 0.059 EUR/each (Table 4). Besides the returns of 39,871 EUR/year (Table 5), the biggest benefit is the independence from external suppliers. An increase in the costs of fingerlings would have only a minimal impact on the KPIs. The critical price threshold for fingerlings in this scenario is $0.128 \mathrm{EUR} /$ fish. If this threshold is undercut at the same output a negative operating result will be achieved again. Among the main problems of own fingerling production, besides high mortality rates and high feed costs [82], there is still a lack of know-how for efficient breeding of healthy fingerlings, as successful hatcheries keep their know-how as company secret. To overcome this knowledge gap, companies need to work closely with research institutions to establish the best possible protocols for seedling production in future.

The scenario of aquaponics integration through a large-scale greenhouse is a critical economic decision. In addition to high investment costs, a greenhouse opens another economic sector with completely different products and requires additional know-how and distribution channels. In the first option, a $1000 \mathrm{~m}^{2}$ tomato greenhouse is integrated. Aquaponic tomato production can be operated commercially and produce marketable fruit if mineral fertilisers are added and the cycles are decoupled, i.e., the fertilised process water from the plants is not recirculated to the fish [65]. Aquaponic tomato cultivation can increase fertilisation efficiency by $23.6 \%$ compared to hydroponic cultivation [65], but the demand for fertilisation is still high. In the case of tomatoes, the main benefits of aquaponic production are improved marketing opportunities of both fish and plants. The increased sales prices improve the aquaculture KPIs (returns 36,459 EUR/year; ROI 3.78\%) and achieve, together with the greenhouse (returns 15,930 EUR/year; ROI 3.91\%), returns of 52,389 EUR/year and an ROI of 3.82\% (Table 5). A study in the U.S. Midwest found that aquaponics systems require higher investment and operating costs and concurrently lower crop production than hydroponics systems, and only become profitable with a $20 \%$ premium price [83]. A 10\% increase in tomato prices would increase the returns and ROI by $25.3 \%$ (65,639 EUR/year; $4.79 \%$ ). Option 2 integrates a highly productive $10,000 \mathrm{~m}^{2}$ basil greenhouse with artificial lighting for year-round production. Basil has already achieved promising results in aquaponics [24]; only small amounts of additional fertilisation, especially with potassium and iron, would be necessary $[25,26]$. The greenhouse (returns 248,502 EUR/year; ROI 6.93\%) together with aquaculture would result in returns of $284,502 \mathrm{EUR} /$ year and an ROI of $6.26 \%$. In 2015, an international survey reported that of 257 aquaponics farms surveyed, of which 188 were classified as "commercial-scale", less than one-third were profitable in the past year [84]. However, the average commercial production site in the US in this study was only $100 \mathrm{~m}^{2}$ of cultivation area and a water volume of $10.3 \mathrm{~m}^{3}$ [84], suggesting that a large proportion of respondents were more likely to be classified as small-scale/semi commercial $\left(\leq 100 \mathrm{~m}^{2}\right)$ [64]. There are contradicting views of aquaponics profitability, but there is consensus that larger systems are economically superior to smaller ones and that profitability depends on retail prices [85]. The integration of a smaller greenhouse is financially viable if the marketing effect spikes higher fish prices. A ten percent increase in basil prices would increase aquaponics KPIs by $71 \%$ (returns 486,377 EUR/year; ROI 10.70\%). For a production of over 2 million pots, an increase in basil prices would primarily be realised through a larger number of retail customers. In the structurally weak northeast of Germany, this is associated with considerably higher transport costs. Furthermore, an integration on this scale is associated with enormous investment costs of several million euros. Larger investments could become interesting especially if European sustainability funds would also subsidise aquaponic investments with $50 \%$. Aquaponic systems have created a strong public perception of sustainable, regional food production. Aquaponic integration would improve the publicity of the company and create a positive customer experience when buying aquaponic products. In order to 
use the marketing advantages most efficiently, the aquaponic principle including fresh plants should be publicly visible for the customers and an additional farm store should be integrated where the end-consumer can buy the fresh products with mark-ups of significantly more than $10 \%$. Since aquaponics is a young field of science, there is still a lot of potential for development, especially with regard to increasing productivity. A particularly productive system for aquaponic basil cultivation has proven to be "aeroponics", a system where the roots grow in the air and are sprayed with process water from the fishes [26].

The last scenario of the higher value-added level is divided into three options. In option 1, hand slaughtering is integrated and $80 \%$ of the production is sold as fillet. At an average fillet price of $6.50 \mathrm{EUR} / \mathrm{kg}$, the company generates still relatively unattractive KPIs with returns of 28.529 EUR/year with an ROI of $2.83 \%$ due to high labour costs (Table 5). However, the higher value of filleting becomes apparent when the fillet price increases due to higher sales to retailers and end-consumer. A ten percent increase in fillet price to $7.15 \mathrm{EUR} / \mathrm{kg}$ increases the two KPIs significantly by $239.4 \%$ and turns the farm into a lucrative business (96,814 EUR/year; $9.59 \%)$. An entrepreneur must calculate at what output the investment in an automated slaughter machine is worthwhile. The advantages for this would be the saving of wages and the identical trimming production. The disadvantages are high investment costs and poorer processing of heterogeneously grown fish. Another option to increase added value is incorporation of additional benefits, because the fish farm can be integrated into the regular farming practices, such as the biogas (CHP, EEG), animal husbandry, crop production and plant irrigation during summer. If a conventional pig fattening is part of the corporation, the ensiled trimmings can be added to the pig feed. The valuable nutrients of the carcass are profitably reused, but only a certain amount can be processed and added to the pig feed $(<10 \%)$, otherwise the pigs reject the feed. Accordingly, a larger pig fattening is required to fully utilise the trimmings. The remaining trimmings are sold far below value (50 EUR/t) to fish meal plants in Cuxhaven, where most of the added value takes place. If poorly planned, disposal to rendering plants (40-100 EUR/t) or biogas plants (10-12 EUR/t) may even incur costs [86]. In order to shift the added value to Mecklenburg-Western Pomerania, the farms would have to chemically ensile or deep-freeze their trimmings and process them centrally (in cooperation) into fish meal or use them directly for the production of dry feed pellet.

In option 2, 30\% of the production is processed into smoked fillets and $50 \%$ into fillets. As smoking is one of the highest processing stages of fish products in northern Germany, the high prices (12.50 EUR/ $\mathrm{kg}$ ) can already generate very lucrative returns of 212,198 EUR/year and an ROI of $20.10 \%$. If the smoked fillet price increases by $10 \%$, returns and ROI increase by $23.2 \%$ (261,442 EUR/year; $24.76 \%)$. In the European trout market, smoked trout accounted for 307 mil. EUR, more than the half of the total intra-EU trade flow (590 mil. EUR.) in 2020 [87]. The main importer among the member states was Germany (308 mil. EUR), with a share of $81 \%$ smoked products ( 249 mil. EUR). Of the global fish and seafood revenue (455.2 bil. USD), processed products accounts for only $28 \%$ and fresh products 55\%, which can be justified by the high share of Asia (293.6 bil. USD), where consumers prefer fresh products [88]. A 2011 analysis of the Egyptian aquaculture value chain concluded that the industry is (i.a.) under increasing financial pressure due to a lack of processing and exports, caused by distrust of processed/ filleted products. [89]. The figures demonstrate that processing is one of the most important parts of the European value chain, which inevitably has to be generated internally within the company or inside the country. The third option extends option 2 by a farm store where $25 \%$ of the total production is sold and direct marketing prices lead to a mark-up of $75 \%$. Despite the additional costs, the company can already generate returns of 297,204 EUR/year and a lucrative ROI of $23.46 \%$. If the farm store can increase prices by another $10 \%$, the two KPIs increase by $15.6 \%$ (343,586 EUR/year; $27.12 \%)$. The farm store could also generate sales by trading additional fishery and agricultural products. The difficulty is that the catfish farms are located in the structurally weakest regions in the northeast of Germany and farm stores integrated in the farm location might not have sufficient clientele to sell $25 \%$ of the 
production. The development of more remote farm stores in areas with higher purchasing power, such as Rostock, Schwerin or Greifswald, could be more profitable, but would incur further costs.

The results from the entrepreneurial decision scenarios show with the background of a 50\% subsidy from the new European fund (EMFAF) that investments remain attractive. Especially by implementing the right entrepreneurial decisions, the industry can become a profitable economic sector. Since a large proportion of the fishery value chain is created in processing, in addition to filleting, higher levels of processing such as smoking should be targeted within the company. To improve sales prices, larger quantities must be distributed to retailers and end-consumer.

\section{Conclusions}

The farmland-based model catfish farm in northern Germany with an output of $320 \mathrm{t}$ /year is currently gainless but economically viable, without consideration of additional benefits. The biggest impact on the profitability of the farm is the selling price, with each ten percent change changing the returns by $\pm 70.463 \mathrm{EUR} /$ year. Among the variable costs, feed has the main impact and accounts for $42.14 \%$ of TC and $61.42 \%$ of VC. This is much lower compared with already analysed pond aquaculture systems where feed can reach $86 \%$ of TC. Each ten percent change in feed price results in a change of returns of $\pm 29.691 \mathrm{EUR} /$ year, followed in descending order by energy ( $10 \%$ price change changes returns by $\pm 5.913 \mathrm{EUR} /$ year), fingerlings ( $\pm 4.804 \mathrm{EUR} /$ year), wages ( $\pm 3.972 \mathrm{EUR} /$ year), and water $( \pm 2.464 \mathrm{EUR} /$ year), which together account for only $24.35 \%$ of TC $(35.49 \%$ of $\mathrm{VC}$ ). If the investment costs can be reduced by $10 \%$, the operating result will change by $\pm 15.546 \mathrm{EUR} /$ year due to lower depreciation.

Different entrepreneurial decision scenarios have significant impact on profitability. A plant size with double the production output can achieve attractive returns of $175,240 \mathrm{EUR} /$ year and an ROI of $11.45 \%$. If the whole fish price increases by $10 \%$, these two ratios increase by $80.4 \%$ (316,167 EUR/year; $20.66 \%)$. This suggests a larger investment if the investors have sufficient capital available. An increase of the maximum stocking density to $550 \mathrm{~kg} / \mathrm{m}^{3}$ may increase the ROI by $4.40 \%$, but risks system malfunctioning and bad publicity. An own fingerling production does not make sense in the case of an exclusive self-supply due to high labour costs, but economically turns positive if three times of the own demand is produced and $200 \%$ is resold to regional breeders. An aquaponic integration of a $1000 \mathrm{~m}^{2}$ tomato greenhouse could result in returns and an ROI of the entire complex of 52,389 EUR/year and 3.82\%. A 10,000 $\mathrm{m}^{2}$ greenhouse with LED lighting for the year-round cultivation of basil, could generate $284,502 \mathrm{EUR} /$ year and an ROI of $6.26 \%$, together with fish farming. The main advantage of aquaponic farming is the principle of sustainable food production, with higher selling prices, reduced waste and reuse of water. Further strategies to enhance the profitability of northern German catfish aquaculture are to keep the added value within the company by increasing the processing stages.

Investments by northern German farmers in catfish aquaculture remain promising due to possible 50\% subsidies of the EMFAF funding program. The farms must ensure that the plants not only contribute to the regional food supply, but also operate economically sustainable. The variable costs of 1,51 EUR/ $\mathrm{kg}$ can be considered as critical, and investors must consider that also for aquaculture in rural areas larger systems (approx. $600 \mathrm{~m}^{3} \mathrm{PV}$ ) are significantly more profitable. Farm sizes of about $300 \mathrm{~m}^{3} \mathrm{PV}$ are more price sensible and dependent on larger distribution volumes to retailers and end customers. Additional synergies can be generated through the establishment of a regional "producer organisation". Together with possible improvements of feed and cultivation techniques together with increasing fish prices, African catfish farms in northern Germany still have large potential for improvement, turning this economically viable aquaculture into an ecological and economical sustainable highly profitable business. 
Author Contributions: All authors contributed to several aspects of the study, specifically, conceptualisation: J.P. and H.W.P.; methodology: J.P. and H.W.P.; software: J.P.; validation: J.P. and H.W.P.; formal analysis: J.P.; investigation: J.P. and H.W.P.; resources: J.P. and H.W.P.; data curation: J.P. and H.W.P.; writing—original draft preparation: J.P.; writing—review and editing: J.P. and H.W.P.; visualisation: J.P.; supervision: H.W.P.; project administration: H.W.P.; funding acquisition: H.W.P. All authors have read and agreed to the published version of the manuscript.

Funding: We thank the Ministry of Agriculture, Environment and Consumer Protection of Mecklenburg-Western Pomerania (Germany), the European Union and EIP-AGRI operational groups for supporting research in aquaponics ('Aquaponik in MV', BNRZD: 13903000 0103; WM-EIP-0007-15). This project was supported in part through the project "Performance and process water management in commercial (integrated) aquaculture systems with African catfish (Clarias gariepinus) in Mecklenburg-Western Pomerania" (MV-II.1-LM-007: 139030000103, EMFF: 7302). This project was also supported by the Steinbeis-Transferzentrum Aquakultur and the Ph. D Scholarship Programme "Unsere Besten promovieren in Rostock" (JP) from the University of Rostock. We thank regional African catfish producers in MV for providing information and highly valuable discussions. We acknowledge financial support from Deutsche Forschungsgemeinschaft and Universität Rostock within the funding programme Open Access Publishing.

Institutional Review Board Statement: Not applicable.

Informed Consent Statement: Not applicable.

Data Availability Statement: The authors follow MDPI's Data Availability Statement.

Conflicts of Interest: The authors declare no conflict of interest.

\section{References}

1. FAO. FishStatJ v4.01.1 (October 2021); FAO: Rome, Italy, 2021.

2. Tacon, A.G.J. Trends in Global Aquaculture and Aquafeed Production: 2000-2017. Rev. Fish. Sci. Aquac. 2020, 28, 43-56. [CrossRef]

3. FAO. The State of World Fisheries and Aquaculture 2020. Sustainability in Action; FAO: Rome, Italy, 2020; p. 206.

4. Bundesministerium für Ernährung und Landwirtschaft (BMEL). Jahresbericht zur Deutschen Binnenfischerei und Binnenaquakultur 2019; BMEL: Bonn, Germany, 2021; p. 61.

5. European Commission. European Green Deal: Commission Adopts Strategic Guidelines for Sustainable and Competitive EU Aquaculture; European Commission: Brussels, Belgium, 2021; p. 2.

6. Badiola, M.; Mendiola, D.; Bostock, J. Recirculating Aquaculture Systems (RAS) analysis: Main issues on management and future challenges. Aquac. Eng. 2012, 51, 26-35. [CrossRef]

7. Martins, C.I.; Schrama, J.W.; Verreth, J.A. The effect of group composition on the welfare of African catfish (Clarias gariepinus). Appl. Anim. Behav. Sci. 2006, 97, 323-334. [CrossRef]

8. EUMOFA, European Commission. Recirculating Aquaculture Systems; Publications Office of the European Union: Luxembourg, 2020; p. 45.

9. Palm, H.; Knaus, U.; Wasenitz, B.; Bischoff, A.; Strauch, S. Proportional up scaling of African catfish (Clarias gariepinus Burchell, 1822) commercial recirculating aquaculture systems disproportionally affects nutrient dynamics. Aquaculture 2018, 491, 155-168. [CrossRef]

10. Asche, F.; Guttormsen, A.G.; Nielsen, R. Future challenges for the maturing Norwegian salmon aquaculture industry: An analysis of total factor productivity change from 1996 to 2008. Aquaculture 2013, 396-399, 43-50. [CrossRef]

11. Jokumsen, A.; Svendsen, L.M. Farming of Freshwater Rainbow Trout in Denmark; DTU Aqua Report no. 219-2010; DTU Aqua, National Institute of Aquatic Resources: Charlottenlund, Denmark, 2010; p. 47.

12. Summerfelt, S.T.; Davidson, J.; May, T.; Good, C.; Vinci, B. Emerging trends in salmonid RAS—Part II. System enhancements. Glob. Aquac. Adv. 2015, 18, 64-65.

13. FAO.org. Available online: https://www.fao.org/fishery/culturedspecies/Sander_lucioperca/en (accessed on 27 October 2021).

14. FAO.org. Available online: https://www.fao.org/fishery/culturedspecies/Clarias_gariepinus/en (accessed on 28 October 2021).

15. Schmidt-Puckhaber, B. Fisch vom Hof?!: Fischerzeugung in Standortunabhängigen Kreislaufanlagen, 1st ed.; DLG-Verlag: Frankfurt, Germany, 2010; p. 144.

16. Statistisches Bundesamt (Destatis). Land und Forstwirtschaft, Fischerei. Erzeugung in Aquakulturbetrieben; Fachserie 3, Reihe 4.6, 2018; Statistisches Bundesamt (Destatis): Wiesbaden, Germany, 2019; p. 54.

17. Hengsawat, K.; Ward, F.; Jaruratjamorn, P.P. The effect of stocking density on yield, growth and mortality of African catfish (Clarias gariepinus Burchell 1822) cultured in cages. Aquaculture 1997, 152, 67-76. [CrossRef]

18. Hossain, M.A.; Beveridge, M.C.; Haylor, G.S. The effects of density, light and shelter on the growth and survival of African catfish (Clarias gariepinus Burchell, 1822) fingerlings. Aquaculture 1998, 160, 251-258. [CrossRef] 
19. van de Nieuwegiessen, P.G.; Olwo, J.; Khong, S.; Verreth, J.; Schrama, J. Effects of age and stocking density on the welfare of African catfish, Clarias gariepinus Burchell. Aquaculture 2009, 288, 69-75. [CrossRef]

20. Pasch, J.; Appelbaum, S.; Knaus, U.; Sandmann, P.; Palm, H.W. Effects of stocking density of African catfish (Clarias gariepinus) life stages in RAS on growth performance and profitability. Aquaculture, under review.

21. Roques, J.A.C.; Schram, E.; Spanings, T.; van Schaik, T.; Abbink, W.; Boerrigter, J.; de Vries, P.; van de Vis, H.; Flik, G. The impact of elevated water nitrite concentration on physiology, growth and feed intake of African catfish Clarias gariepinus (Burchell 1822). Aquac. Res. 2015, 46, 1384-1395. [CrossRef]

22. Schram, E.; Roques, J.A.; Abbink, W.; Spanings, T.; de Vries, P.; Bierman, S.; van de Vis, H.; Flik, G. The impact of elevated water ammonia concentration on physiology, growth and feed intake of African catfish (Clarias gariepinus). Aquaculture 2010, 306, 108-115. [CrossRef]

23. Wasenitz, B.; Karl, H.; Palm, H.W. Composition and quality attributes of fillets from different catfish species on the German market. J. Food Saf. Food Qual. 2018, 69, 57-65.

24. Knaus, U.; Pribbernow, M.; Xu, L.; Appelbaum, S.; Palm, H.W. Basil (Ocimum basilicum) cultivation in decoupled aquaponics with three hydro-components (grow pipes, raft, gravel) and African catfish (clarias gariepinus) production in Northern Ger-many. Sustainability 2020, 12, 8745. [CrossRef]

25. Pasch, J.; Ratajczak, B.; Appelbaum, S.; Palm, H.; Knaus, U. Growth of Basil (Ocimum basilicum) in DRF, Raft, and Grow Pipes with Effluents of African Catfish (Clarias gariepinus) in Decoupled Aquaponics. AgriEngineering 2021, 3, 6. [CrossRef]

26. Pasch, J.; Appelbaum, S.; Palm, H.; Knaus, U. Growth of Basil (Ocimum basilicum) in Aeroponics, DRF, and Raft Systems with Effluents of African Catfish (Clarias gariepinus) in Decoupled Aquaponics (s.s.). AgriEngineering 2021, 3, 36. [CrossRef]

27. Knaus, U.; Wenzel, L.; Appelbaum, S.; Palm, H. Aquaponics (s.l.) Production of Spearmint (Mentha spicata) with African Catfish (Clarias gariepinus) in Northern Germany. Sustainability 2020, 12, 8717. [CrossRef]

28. Oladimeji, S.A.; Okomoda, V.T.; Olufeagba, S.O.; Solomon, S.G.; Abol-Munafi, A.B.; Alabi, K.I.; Ikhwanuddin, M.; Martins, C.O.; Umaru, J.; Hassan, A. Aquaponics production of catfish and pumpkin: Comparison with conventional production sys-tems. Food Sci. Nutr. 2020, 8, 2307-2315. [CrossRef] [PubMed]

29. EC.europa.eu. Available online: https:/ / ec.europa.eu/oceans-and-fisheries/funding/european-maritime-and-fisheries-fundemff_en (accessed on 27 October 2021).

30. Umweltbundesamt.de. Available online: https://www.umweltbundesamt.de/themen/klima-energie/erneuerbare-energien/ erneuerbare-energien-gesetz\#erfolg (accessed on 27 October 2021).

31. BMWI.de. Available online: https://www.bmwi.de/Redaktion/DE/Artikel/Energie/moderne-kraftwerkstechnologien.html (accessed on 27 October 2021).

32. Engle, C.R.; Kumar, G.; Van Senten, J. Cost drivers and profitability of U.S. pond, raceway, and RAS aquaculture. J. World Aquac. Soc. 2020, 51, 847-873. [CrossRef]

33. Xiao, R.; Wei, Y.; An, D.; Li, D.; Ta, X.; Wu, Y.; Ren, Q. A review on the research status and development trend of equipment in water treatment processes of recirculating aquaculture systems. Rev. Aquac. 2019, 11, 863-895. [CrossRef]

34. Heiderscheidt, E.; Tesfamariam, A.; Pulkkinen, J.; Vielma, J.; Ronkanen, A.-K. Solids management in freshwater-recirculating aquaculture systems: Effectivity of inorganic and organic coagulants and the impact of operating parameters. Sci. Total Environ. 2020, 742, 140398. [CrossRef]

35. Gibson, T.F.; Watanabe, W.O.; Losordo, T.M.; Whitehead, R.F.; Carroll, P.M. Evaluation of chemical polymers as coagulation aids to remove suspended solids from marine finfish recirculating aquaculture system discharge using a geotextile bag. Aquac. Eng. 2020, 90, 102065. [CrossRef]

36. Villar-Navarro, E.; Garrido-Pérez, C.; Perales, J.A. The potential of different marine microalgae species to recycle nutrients from recirculating aquaculture systems (RAS) fish farms and produce feed additives. Algal Res. 2021, 58, 102389. [CrossRef]

37. Yogev, U.; Vogler, M.; Nir, O.; Londong, J.; Gross, A. Phosphorous recovery from a novel recirculating aquaculture system followed by its sustainable reuse as a fertilizer. Sci. Total Environ. 2020, 722, 137949. [CrossRef] [PubMed]

38. Chen, Z.; Chang, Z.; Qiao, L.; Wang, J.; Yang, L.; Liu, Y.; Song, X.; Li, J. Nitrogen removal performance and microbial diversity of bioreactor packed with cellulosic carriers in recirculating aquaculture system. Int. Biodeterior. Biodegradation 2021, $157,105157$. [CrossRef]

39. Ruiz, P.; Vidal, J.M.; Sepúlveda, D.; Torres, C.; Villouta, G.; Carrasco, C.; Aguilera, F.; Ruiz-Tagle, N.; Urrutia, H. Overview and future perspectives of nitrifying bacteria on biofilters for recirculating aquaculture systems. Rev. Aquac. 2019, 12, 1478-1494. [CrossRef]

40. Jiang, W.; Tian, X.; Li, L.; Dong, S.; Zhao, K.; Li, H.; Cai, Y. Temporal bacterial community succession during the start-up process of biofilters in a cold-freshwater recirculating aquaculture system. Bioresour. Technol. 2019, 287, 121441. [CrossRef] [PubMed]

41. Rojas-Tirado, P.A.; Pedersen, P.B.; Pedersen, L.-F. Bacterial activity dynamics in the water phase during start-up of recirculating aquaculture systems. Aquac. Eng. 2017, 78, 24-31. [CrossRef]

42. Ekawati, A.W.; Ulfa, S.M.; Dewi, C.S.U.; Aziz, A.; Amin, L.N.M.S.; Yanuar, A.T.; Kurniawan, A. Analysis of AquaponicRecirculation Aquaculture System (A-Ras) Application in the Catfish (Clarias gariepinus) Aquaculture in Indonesia. Aquaculture 2021, 21, 93-100. [CrossRef]

43. Supajaruwong, S.; Satanwat, P.; Pungrasmi, W.; Powtongsook, S. Design and function of a nitrogen and sediment removal system in a recirculating aquaculture system optimized for aquaponics. Environ. Eng. Res. 2020, 26, 190494. [CrossRef] 
44. Calone, R.; Pennisi, G.; Morgenstern, R.; Sanyé-Mengual, E.; Lorleberg, W.; Dapprich, P.; Winkler, P.; Orsini, F.; Gianquinto, G. Improving water management in European catfish recirculating aquaculture systems through catfish-lettuce aquaponics. Sci. Total Environ. 2019, 687, 759-767. [CrossRef]

45. O'Rourke, P.D. The economics of recirculating aquaculture systems. In Proceedings of the 1st International Conference on Recirculating Aquaculture, Virginia Polytechnic Institute and State University, Roanoke, VA, USA, 20-23 July 1996; pp. 1-19.

46. Aich, N.; Nama, S.; Biswal, A.; Paul, T. A review on recirculating aquaculture systems: Challenges and opportunities for sustainable aquaculture. Innov. Farming 2020, 5, 17-24.

47. Ngoc, P.T.A.; Meuwissen, M.P.M.; Tru, L.C.; Bosma, R.H.; Verreth, J.; Lansink, A.O. Economic feasibility of recirculating aquaculture systems in pangasius farming. Aquac. Econ. Manag. 2016, 20, 185-200. [CrossRef]

48. Om, A.D.; Yusoff, N.H.N.; Jamari, Z. Evaluation of economics feasibility on marine fish seeds nursed in local backyard recirculating aquaculture system (RAS). Int. J. Fish. Aquat. Stud. 2020, 8, 288-293.

49. Ranjan, R.; Megarajan, S.; Xavier, B.; Raju, S.S.; Ghosh, S.; Gopalakrishnan, A. Design and performance of recirculating aquaculture system for marine finfish broodstock development. Aquac. Eng. 2019, 85, 90-97. [CrossRef]

50. de Souza Motta, J.H.; Vidal Júnior, M.V.; Glória, L.S.; Cruz Neto, M.A.; Silveira, L.S.D.; Andrade, D.R.D. Technical and economic feasibility of food strategies in the hatchery of Cyprinus carpio (Cypriniformes, Cyprinidae) in a recirculating aquaculture system. Latin Am. J. Aquat. Res. 2019, 47, 626-637.

51. Kristan, J.; Blecha, M.; Policar, T. Survival and growth rates of juvenile Grass Carp Ctenopharyngodon idella overwintered in ponds and recirculating aquaculture systems including a comparison of production economics. Turk. J. Fish. Aquat. Sci. 2018, 19, 261-266.

52. Pereira, D.A.S.; Henriques, M.B. Economic feasibility for producing Imperial Zebra pleco (Hypancistrus zebra) in recirculating aquaculture systems: An alternative for a critically endangered ornamental fish. Aquac. Econ. Manag. 2019, 23, 428-448. [CrossRef]

53. Mohammad, T.; Moulick, S.; Mukherjee, C.K. Economic feasibility of goldfish (Carassius auratus Linn.) recirculating aquaculture system. Aquac. Res. 2018, 49, 2945-2953. [CrossRef]

54. Diatin, I.; Shafruddin, D.; Hude, N.; Sholihah, M.; Mutsmir, I. Production performance and financial feasibility analysis of farming catfish (Clarias gariepinus) utilizing water exchange system, aquaponic, and biofloc technology. J. Saudi Soc. Agric. Sci. 2021, 20, 344-351. [CrossRef]

55. Oké, V.; Goosen, N. The effect of stocking density on profitability of African catfish (Clarias gariepinus) culture in extensive pond systems. Aquaculture 2019, 507, 385-392. [CrossRef]

56. Oluwalola, O.; Fagbenro, O.; Adebayo, O. Growth and Economic Performances of African Catfish, Clarias gariepinus Reared under Different Culture Facilities. Afr. J. Fish. Aquat. Resour. Manag. 2019, 4, 75-84.

57. Asche, F.; Roll, K.H.; Tveteras, R. Economic inefficiency and environmental impact: An application to aquaculture production. J. Environ. Econ. Manag. 2009, 58, 93-105. [CrossRef]

58. El-Sayed, A.-F.; Dickson, M.; El-Naggar, G.O. Value chain analysis of the aquaculture feed sector in Egypt. Aquaculture 2015, 437, 92-101. [CrossRef]

59. Guttormsen, A.G. Input Factor Substitutability in Salmon Aquaculture. Mar. Resour. Econ. 2002, 17, 91-102. [CrossRef]

60. Coppens.de. Available online: https://static.alltechcoppens.com/assets/DE_CATFISH_2021.pdf?mtime=20210209101004 \&focal=none (accessed on 28 October 2021).

61. Coppens.de. Available online: https://www.alltechcoppens.com/de/aktuelles/farming-catfish-in-ras (accessed on 28 October 2021).

62. KTBL.de. Available online: https://www.ktbl.de/webanwendungen/baukost-gewaechshaeuser (accessed on 28 October 2021).

63. KTBL.de. Available online: https://www.ktbl.de/webanwendungen/gemuese-im-geschuetzten-anbau (accessed on 28 October 2021).

64. Palm, H.W.; Knaus, U.; Appelbaum, S.; Goddek, S.; Strauch, S.M.; Vermeulen, T.; Jijakli, M.H.; Kotzen, B. Towards commercial aquaponics: A review of systems, designs, scales and nomenclature. Aquac. Int. 2018, 26, 813-842. [CrossRef]

65. Suhl, J.; Dannehl, D.; Kloas, W.; Baganz, D.; Jobs, S.; Scheibe, G.; Schmidt, U. Advanced aquaponics: Evaluation of intensive tomato production in aquaponics vs. conventional hydroponics. Agric. Water Manag. 2016, 178, 335-344. [CrossRef]

66. Microsoft $^{\circledR}$ Corporation. Microsoft Excel ${ }^{\circledR}$; Microsoft Corporation: Redmond, WA, USA, 2010.

67. Benker, H. Excel in der Wirtschaftsmathematik. In Excel in der Wirtschaftsmathematik, 1st ed.; Benker, H., Ed.; Springer: Wiesbaden, Germany, 2014; Volume 1, pp. 93-97.

68. EC.europa.eu. Available online: https://ec.europa.eu/oceans-and-fisheries/funding/emfaf_en (accessed on 28 October 2021).

69. Service.m-v.de. Available online: https://www.service.m-v.de/foerderfibel/?sa.fofifoerderung.foerderung_id=24\&sa.fofi. kategorie_id=1 (accessed on 28 October 2021).

70. Kumar, G.; Engle, C.; Tucker, C. Costs and Risk of Catfish Split-pond Systems. J. World Aquac. Soc. 2016, 47, 327-340. [CrossRef]

71. Morach, B.; Witte, B.; Walker, D.; von Koeller, E.; Grosse-Holz, F.; Rogg, J.; Brigl, M.; Dehnert, N.; Obloj, P.; Koktenturk, S.; et al. Food for Thought: The Protein Transformation. Ind. Biotechnol. 2021, 17, 125-133. [CrossRef]

72. Statista.com. Available online: https://de.statista.com/statistik/daten/studie/1905/umfrage/entwicklung-des-pro-kopfverbrauchs-an-fisch-in-deutschland/ (accessed on 28 October 2021).

73. Statista.com. Available online: https://de.statista.com/outlook/cmo/lebensmittel/fisch-meeresfruechte/deutschland\# vertriebskanaele (accessed on 28 October 2021). 
74. Omobepade, B.P.; Adebayo, O.T.; Amos, T.T.; Adedokun, B.C. Profitability analysis of aquaculture in ekiti state, Nigeria. Niger. J. Agric. Food Environ. 2015, 11, 114-119.

75. Hasan, M.R. On-farm feeding and feed management in aquaculture. FAO Aquac. Newsl. 2010, 45, 48.

76. Jannathulla, R.; Rajaram, V.; Kalanjiam, R.; Ambasankar, K.; Muralidhar, M.; Dayal, J.S. Fishmeal availability in the scenarios of climate change: Inevitability of fishmeal replacement in aquafeeds and approaches for the utilization of plant protein sources. Aquac. Res. 2019, 50, 3493-3506. [CrossRef]

77. Palm, H.W.; Berchtold, E.; Gille, B.; Knaus, U.; Wenzel, L.C.; Baßmann, B. Growth and Welfare of African catfish (Clarias gariepinus Burchell, 1822) under dietary supplementation of the mixed layer clay mineral montmorillonite-illlite/muscovite (1g557) in commercial aquaculture. Aquaculture 2021, under review.

78. Badiola, M.; Basurko, O.C.; Piedrahita, R.; Hundley, P.; Mendiola, D. Energy use in Recirculating Aquaculture Systems (RAS): A review. Aquac. Eng. 2018, 81, 57-70. [CrossRef]

79. Gruene.de. Available online: https://www.gruene.de/artikel/wahlprogramm-zur-bundestagswahl-2021 (accessed on 26 November 2021).

80. DGB.de. Available online: https://www.dgb.de/themen/++co++6ca263de-fb0e-11e9-bdcf-52540088cada (accessed on 28 October 2021).

81. SPD.de. Available online: https://www.spd.de/aktuelles/detail/news/mindestlohn-von-12-euro-notwendig-und-richtig/14 /09/2021/ (accessed on 28 October 2021).

82. Nyonje, B.M.; Opiyo, M.A.; Orina, P.S.; Abwao, J.; Wainaina, M.; Charo-Karisa, H. Current status of freshwater fish hatcheries, broodstock management and fingerling production in the Kenya aquaculture sector. Livest. Res. Rural. Dev. 2018, 30, 1-8.

83. Quagrainie, K.K.; Flores, R.M.V.; Kim, H.-J.; McClain, V. Economic analysis of aquaponics and hydroponics production in the U.S. Midwest. J. Appl. Aquac. 2018, 30,1-14. [CrossRef]

84. Love, D.C.; Fry, J.P.; Li, X.; Hill, E.S.; Genello, L.; Semmens, K.; Thompson, R.E. Commercial aquaponics production and profitability: Findings from an international survey. Aquaculture 2015, 435, 67-74. [CrossRef]

85. Greenfeld, A.; Becker, N.; McIlwain, J.; Fotedar, R.; Bornman, J.F. Economically viable aquaponics? Identifying the gap between potential and current uncertainties. Rev. Aquac. 2019, 11, 848-862. [CrossRef]

86. Valbuena, I.; Bechstein, F.; Erdös, A.; Müller-Belecke, A.; Donath, W.; Kaufhold, S. Konzeptstudie zur Erzeugung von Trockenfuttermitteln aus Konservierten Nebenprodukten der Süßwasserfischverarbeitung und deren Verwertung Durch Karnivore Wirtschaftsfischarten; DBU: Osnabrück, Germany, 2012; p. 76.

87. EUMOFA, European Commission. Case Study, Portion Trout in the EU, Price Structure in the Supply Chain; Publications Office of the European Union: Luxembourg, 2021; p. 58.

88. Frimpong, J. Fish E Seafood Report 2021; Statista: Hamburg, Germany, 2021; p. 34.

89. Macfadyen, G.; Nasr-Alla, A.M.; Al-Kenawy, D.; Fathi, M.; Hebicha, H.; Diab, A.M.; Mohmed, S.; Ramadan, H.; Abou-Zeid, M.; El-Naggar, G. Value-chain analysis-An assessment methodology to estimate Egyptian aquaculture sector performance. Aquaculture 2012, 362, 18-27. [CrossRef] 